\title{
Aerosol radiative forcing during African desert dust events (2005-2010) over Southeastern Spain
}

\author{
A. Valenzuela ${ }^{1,2}$, F. J. Olmo ${ }^{1,2}$, H. Lyamani ${ }^{1,2}$, M. Antón ${ }^{1,2}$, A. Quirantes ${ }^{1}$, and L. Alados-Arboledas ${ }^{1,2}$ \\ ${ }^{1}$ Departamento de Física Aplicada, Universidad de Granada, Granada, Spain \\ ${ }^{2}$ Centro Andaluz de Medio Ambiente (CEAMA), Granada, Spain
}

Correspondence to: A. Valenzuela (avalenzuela@ugr.es)

Received: 23 January 2012 - Published in Atmos. Chem. Phys. Discuss.: 2 March 2012

Revised: 14 September 2012 - Accepted: 17 September 2012 - Published: 6 November 2012

\begin{abstract}
The daily ( $24 \mathrm{~h}$ ) averages of the aerosol radiative forcing (ARF) at the surface and the top of the atmosphere (TOA) were calculated during desert dust events over Granada (southeastern Spain) from 2005 to 2010. A radiative transfer model (SBDART) was utilized to simulate the solar irradiance values $(0.31-2.8 \mu \mathrm{m})$ at the surface and TOA, using as input aerosol properties retrieved from CIMEL sun photometer measurements via an inversion methodology that uses the sky radiance measurements in principal plane configuration and a spheroid particle shape approximation. This inversion methodology was checked by means of simulated data from aerosol models, and the derived aerosol properties were satisfactorily compared against well-known AERONET products. Good agreement was found over a common spectral interval $(0.2-$ $4.0 \mu \mathrm{m}$ ) between the simulated SBDART global irradiances at surface and those provided by AERONET. In addition, simulated SBDART solar global irradiances at the surface have been successfully validated against CM-11 pyranometer measurements. The comparison indicates that the radiative transfer model slightly overestimates (mean bias of $3 \%$ ) the experimental solar global irradiance. These results show that the aerosol optical properties used to estimate ARF represent appropriately the aerosol properties observed during desert dust outbreak over the study area. The ARF mean monthly values computed during desert dust events ranged from $-13 \pm 8 \mathrm{~W} \mathrm{~m}^{-2}$ to $-34 \pm 15 \mathrm{~W} \mathrm{~m}^{-2}$ at surface, from $-4 \pm 3 \mathrm{~W} \mathrm{~m}^{-2}$ to $-13 \pm 7 \mathrm{~W} \mathrm{~m}^{-2}$ at TOA and from $+6 \pm 4$ to $+21 \pm 12 \mathrm{~W} \mathrm{~m}^{-2}$ in the atmosphere. We have checked if the differences found in aerosol optical properties among desert dust sectors translate to differences in ARF. The mean ARF at surface (TOA) were $-20 \pm 12(-5 \pm 5) \mathrm{W} \mathrm{m}^{-2}$,
\end{abstract}

$-21 \pm 9(-7 \pm 5) \mathrm{W} \mathrm{m}^{-2}$ and $-18 \pm 9(-6 \pm 5) \mathrm{W} \mathrm{m}^{-2}$ for sector A (northern Morocco; northwestern Algeria), sector B (western Sahara, northwestern Mauritania and southwestern Algeria), and sector C (eastern Algeria, Tunisia), respectively. The Kolmogorov-Smirnov statistical test revealed that daily ARF values at TOA for sector A were significantly different from the other two sectors, likely as a result of the lower values of single scattering albedo obtained for sector A. The mean values of aerosol radiative forcing efficiency at surface (TOA) were $-74 \pm 12 \mathrm{~W} \mathrm{~m}^{-2}\left(-17 \pm 7 \mathrm{~W} \mathrm{~m}^{-2}\right)$ for sector $\mathrm{A},-70 \pm 14 \mathrm{~W} \mathrm{~m}^{-2}\left(-20 \pm 9 \mathrm{~W} \mathrm{~m}^{-2}\right)$ for sector $\mathrm{B}$, and $-65 \pm 16 \mathrm{~W} \mathrm{~m}^{-2}\left(-22 \pm 10 \mathrm{~W} \mathrm{~m}^{-2}\right)$ for sector $\mathrm{C}$, and thus comparable between the three sectors in all seasons.

\section{Introduction}

Mineral dust is one of the main constituents of the atmospheric aerosol that determine the radiation budget of the atmosphere. The evaluation of the dust-radiation interaction is essential for climate forcing assessment at both local and regional scales. However, large uncertainties still remain in assessing the dust climate impacts (Foster et al., 2007). One of the major sources of uncertainty in dust radiative forcing is associated with dust optical and physical properties due to complexities in dust size distribution, morphology, and mineral composition (Sokolik and Toon, 1999).

The Sahara desert is the most important source of mineral dust in the Northern Hemisphere (e.g. Prospero et al., 2002). North African dust is injected into the atmosphere through resuspension processes in source areas, and transported at different altitudes (up to $7 \mathrm{~km}$ ) to different areas of the world 
(e.g. Tesche et al., 2009). Papayannis et al. (2008) reported more than 130 observation days of the horizontal and vertical extent of Saharan dust intrusions over Europe by means of a coordinated lidar network in the frame of the European Aerosol Research Lidar Network (EARLINET). They found that Saharan dust source regions play a key role in dust transport to Europe for the height layer between 3 and $5 \mathrm{~km}$.

The Iberian Peninsula is frequently affected by African dust intrusions with large aerosol loads that modulate the aerosol climatology in different areas of this region, especially in southern Spain (e.g. Toledano et al., 2007; Cachorro et al., 2008; Rascado et al., 2008, 2009; Antón et al., 2012) and Portugal (e.g. Wagner et al., 2009). The sign and magnitude of the aerosol radiative forcing (ARF) associated with these intrusions depend on dust scattering and absorbing properties that are controlled by a number of properties such as dust size distribution, chemical composition, particle mixing state and shapes (e.g. Otto et al., 2009). Close to the source region mostly pure dust is found, but after long-range transport the aging of dust and mixing with other aerosol types modify the optical properties of desert dust (e.g. Bauer et al., 2011). Several studies have shown that mineral dust in the atmosphere is often mixed with anthropogenic aerosol (e.g. Kandler et al., 2007; Gangoiti et al., 2006). Recently, Rodríguez et al. (2011) showed that anthropogenic emissions from crude oil refineries and power plants, located on Northern African coasts, contribute to desert dust mixing with particulate pollutants. Hence, the contribution of anthropogenic particles emitted from such regions can be relevant during African dust outbreaks over Mediterranean sites. This fact is suggested by the relatively high Angström exponent $(\alpha)$ values - measured after medium-long range dust transport in comparison with those obtained in source areas - and confirmed by analyses of chemical composition of ground-collected particles (e.g. Bellantone et al., 2008; Carofalo et al., 2008). Thus, several authors have pointed out the importance of taking into account the influence of anthropogenic particles on the direct radiative forcing associated with African desert dust intrusions over the Mediterranean basin and continental Europe (e.g., Gerasopoulos et al., 2003; Perrone and Bergamo, 2011).

In a recent paper, Valenzuela et al. (2012a) analyzed columnar aerosol radiative properties during African dust intrusions over Granada, reporting values of the single scattering albedo $\omega(\lambda)$ smaller than those found at other locations explained by the mixing of desert dust with absorbing particles from anthropogenic origin. Knowledge of the variability in absorption properties of these aerosol mixtures is particularly important for assessing the direct radiative forcing of these aerosol types (e.g. Garcia et al., 2011).

The shapes of dust particles are irregular (e.g. Koren et al., 2001; Muñoz et al., 2001). Theoretical studies of dust optical properties based on a spheroid polydispersion model have shown that dust properties can be substantially different from those obtained with Lorenz-Mie theory adopt- ing spherical models (e.g. Mishchenko et al., 1997). Certain spheroidal shape parameterizations can substantially diminish the differences between experimental and modeled values of the atmospheric aerosol radiative forcing (Otto et al., 2009). Yang et al. (2007) estimated the influence of prolate spheroidal model particles on the radiation field and stated that the nonsphericity of particles affects short-wave radiation significantly, but has no impact on long-wave radiation. Pilinis and $\mathrm{Li}$ (1998) estimated the radiative forcing of prolate spheroidal model particles, and found that assuming such shapes can result in a radiative forcing up to three times larger than for spherical shapes when the solar zenith angle nears zero. These authors found that the assumption of particle shape is important for the upwelling scattered radiation, especially for small solar zenith angles and super-micron particles, and that the upward scattered radiation is underestimated when assuming spherical particles.

During recent years, different inversion methods have been proposed to retrieve aerosol microphysical properties using sun and sky radiance measurements in the almucantar or principal plane configurations (e.g. Nakajima et al., 1996; Vermeulen et al., 2000; Dubovik and King, 2000; Dubovik et al., 2002a, 2006; Olmo et al., 2006, 2008). Applying such methods to sky radiance and sun-photometric measurements in the almucantar configuration, many authors have presented results of columnar aerosol optical and microphysical properties (e.g. Dubovik et al., 2002b; Kubilay et al., 2003; Lyamani et al., 2006b; Tafuro et al., 2006; Olmo et al., 2006; Cachorro et al., 2008; Pinker et al., 2010; Eck et al., 2010; Garcia et al., 2011). However, few authors have presented optical properties retrieved using sky radiance measurements in the principal plane configuration (e.g. Li et al., 2004; Dubovik et al., 2006; Olmo et al., 2008; Valenzuela et al., 2012a,b). Sky radiance measurements in the solar principal plane have received less attention than almucantar sky radiance measurements due to the difficulties in data quality assurance. In fact, the AERONET network routinely distributes only almucantar retrievals. One of the major difficulties in retrieving aerosol properties from sky radiance in principal plane is the screening of partially cloud-contaminated data. Using almucantar measurements, these cloud-affected data can be detected by checking the symmetry of left and right almucantar scans. However, the symmetry criteria cannot be applied for principal plane observations and therefore, screening partially cloudy principal plane data is more difficult.

The sky radiance measurements in the principal plane allow us to obtain columnar optical and microphysical aerosol properties throughout the day, not just for large solar zenith angles as in the almucantar configuration. In this study we used the aerosol optical properties retrieved by the principal plane inversion method described by Olmo et al. (2008). This inversion method uses a spheroid particle model similar to that used in AERONET (Dubovik et al., 2006) to account for particle nonsphericity in modeling aerosol properties. A 
similar spheroid model was used by Kobayashi et al. (2010) to retrieve optical properties of nonspherical aerosols using SKYRAD.PACK (Nakajima et al.,1996) in the almucantar configuration.

The main objective of this study is to quantify the aerosol radiative effect at the surface and TOA during African desert dust intrusions over Granada (southeastern Spain) from 2005 to 2010, on temporal scales ranging from daily to seasonal. In addition, the aerosol radiative forcing per unit of aerosol optical depth (aerosol radiative forcing efficiency) during these intrusions is analyzed according to the desert dust source.

This paper is structured as follows: Sect. 2 presents the experimental site and instrumentation used. Section 3 describes the methodology applied. Section 4 discusses the results. Section 5 summarizes the main conclusions. Appendix A presents sensitivity tests of the principal plane inversion method used in this work.

\section{Experimental site and instrumentation}

The instruments used in this study are installed at the Andalusian Center for Environmental Studies (CEAMA) in Granada $\left(37.16^{\circ} \mathrm{N}, 3.61^{\circ} \mathrm{W}\right.$ and $680 \mathrm{~m}$ a.s.l.). Granada, located in southeastern Spain, is a nonindustrialized, medium-sized city with a population of 300000 . The city is situated in a natural basin surrounded by mountains with altitudes over 1000 $\mathrm{m}$. The near-continental conditions prevailing at this site are responsible for large seasonal temperature differences, providing cool winters and hot summers. The study area also experiences periods of low humidity regime, especially in the summer. The study area is about $200 \mathrm{~km}$ from the African continent, and approximately $50 \mathrm{~km}$ from the western Mediterranean basin. Due to its proximity to the African continent our study area is often affected by African dust intrusions (e.g. Lyamani et al., 2005a, 2006a; Olmo et al., 2006, 2008; Valenzuela et al., 2012b).

Column-integrated characterization of the atmospheric aerosol has been performed by means of a sun photometer CIMEL CE-318-4 included in the AERONET network (Holben et al., 1998). This sun photometer makes direct sun measurements with a $1.2^{\circ}$ full field of view at $340,380,440,670$, 870,940 and $1020 \mathrm{~nm}$. The full-width of the interference filters at half-maximum are $2 \mathrm{~nm}$ at $340 \mathrm{~nm}, 4 \mathrm{~nm}$ at $380 \mathrm{~nm}$ and $10 \mathrm{~nm}$ at all other wavelengths. In addition, the CIMEL instrument performs sky radiance measurements, both in almucantar and principal plane configurations, at 440, 670, 870 and $1020 \mathrm{~nm}$. Calibrations of this instrument were performed by the AERONET-RIMA network, and assumed calibration errors are lower than $5 \%$. More details about this instrument are given by Holben et al. (1998).

Torres (2012) analyzes error sources in sky radiance measurements like those associated with pointing or field of view. The pointing errors, due to motor degradation and misalignments, depend on the scattering angle, being in the range 0 $0.4^{\circ}$ for middle latitude stations. According to Torres (2012), these pointing errors can affect more strongly the principal plane (especially the vertical error) than the almucantar measurements. On the other hand, errors in radiance measurements associated with the field of view are small or negligible. The effect of these errors on the retrieval procedure will be discussed in Sect. 3.4.

Solar global irradiance measurements in the $0.31-2.8 \mu \mathrm{m}$ range were obtained by a CM-11 pyranometer (Kipp and Zonen, Delft, Netherlands). The CM-11 complies with the specifications for the first-class WMO classification of this instrument (resolution better than $\pm 5 \mathrm{~W} \mathrm{~m}^{-2}$ ). This instrument has been periodically calibrated at the study site using a reference CM-11 instrument which is only used for intercomparison purposes. Four intercomparisons were performed between March 2005 and June 2010, with variations smaller than $1 \%$ for the entire measurement period, showing the great stability of the instrument used in this study.

An All-Sky Imager, developed by the GFAT (Atmospheric Physics group of the University of Granada), was used to routinely obtain images of the whole sky dome in the daytime. This instrument has been used for cloud cover and atmospheric aerosol characterizations (Cazorla et al., 2008, 2009). The All-Sky Imager is a custom adaptation of a scientific CCD camera, using a digital color video camera mounted with a fish-eye lens $\left(180^{\circ} \mathrm{FOV}\right)$ pointing at the zenith.

In this paper we used the data set registered during the desert dust events over Granada (southeastern Spain) from 2005 to 2010.

\section{Methodology and data}

\subsection{Inversion method}

The inversion method of Olmo et al. (2008) used in this study is based on the original method developed by Nakajima et al. (1996), SKYRAD.PACK, that gives the option to invert the almucantar or the principal plane sky radiance measurements. Whereas the original method is based on a spherical particle assumption, desert dust particles have nonspherical shapes, so Olmo et al. (2008) updated the SKYRAD.PACK code with a spheroid-based model to account for particle nonsphericity in modelling aerosol properties. Furthermore, these authors implemented an iterative procedure to derive the aerosol refractive index and other aerosol parameters. A detailed description of the inversion method used in this study is given below.

The inversion method uses as input data the spectral aerosol optical depths, derived from sun photometer extinction measurements by using Beer-Bouger-Lambert law given by

$$
V(\lambda)=V_{o}(\lambda) \exp \left(-m_{o} \tau_{\mathrm{ext}}(\lambda)\right)
$$


where $V(\lambda)$ is the signal measured by the sun photometer, $V_{o}(\lambda)$ is the calibration constant, $m_{o}$ is the optical air mass and $\tau_{\text {ext }}(\lambda)$ is the total atmospheric optical depth. Calibration of the sun photometer used in this study was performed annually by the AERONET-RIMA network.

Using Eq. (1), $\tau_{\text {ext }}(\lambda)$ is derived from direct sun photometer measurements using the appropriate calibration constants provided by AERONET (linear rate change in time is assumed for calibration constants). Therefore, the spectral aerosol optical depth, $\tau_{a}(\lambda)$, is obtained by subtracting the Rayleigh optical depth as well as the optical depths for $\mathrm{O}_{3}$ and $\mathrm{NO}_{2}$ from $\tau_{\text {ext }}(\lambda)$ following the methodology described by Alados-Arboledas et al. (2003, 2008). Ozone content is obtained from an OMI instrument on board the AURA satellite (http://aura.gsfc.nasa.gov/instruments/omi. html). The $\mathrm{NO}_{2}$ content used is $0.00017 \mathrm{~cm}$-atm given by Kneizys et al. (1988) for mid-latitudes atmosphere. The total estimated uncertainty in $\tau_{a}(\lambda)$ is of \pm 0.01 for $\lambda>440 \mathrm{~nm}$ and \pm 0.02 for shorter wavelengths (Alados-Arboledas et al., 2003).

In addition, for more accurate aerosol property retrievals, the inversion code uses as input the monochromatic sky radiance normalized by the monochromatic direct solar irradiance, $R(\Theta, \lambda)$, instead of the monochromatic sky radiance; the latter is a magnitude less affected by interference-filter degradation of sun photometers, and can be more accurately determined. The $R(\Theta, \lambda)$ is given by

$$
\begin{aligned}
R(\Theta, \lambda) & =\frac{E(\Theta, \lambda)}{F_{\lambda} m_{o} \Delta \Omega}=\omega(\lambda) \tau_{\mathrm{ext}}(\lambda) P(\Theta, \lambda)+q(\Theta, \lambda) \\
& =\beta(\Theta, \lambda)+q(\Theta, \lambda)
\end{aligned}
$$

where $E(\Theta, \lambda)$ is the monochromatic sky radiance $\left(\mathrm{Wm}^{-2} \mu \mathrm{m}^{-1} \mathrm{sr}^{-1}\right) ; \quad F_{\lambda}$ is the monochromatic direct solar irradiance $\left(\mathrm{Wm}^{-2} \mu \mathrm{m}^{-1}\right) ; \Delta \Omega$ is the solid view angle of the sky radiometer; $\omega(\lambda)$ and $P(\Theta, \lambda)$ are the total single scattering albedo and phase function at scattering angle $\Theta ; \beta(\Theta, \lambda)$ is the total differential scattering coefficient (single scattering term), that is the sum of the scattering coefficients for aerosol and molecules; and $q(\Theta, \lambda)$ is the multiple-scattering contribution. $E(\Theta, \lambda)$ and $F_{\lambda}$ are obtained from sun photometer measurements using the calibration constants provided by AERONET-RIMA.

In the solution approach of Eq. (2), atmospheric layers are characterized by their optical depth, single scattering albedo and phase function. The scattering properties of an atmospheric aerosol layer are modelled by averaging single-particle properties. To derive the solutions, the SKYRAD.PACK code uses the spherical approximation for single-particle properties. However, in the modified version used in this study (Olmo et al., 2008), the aerosol singlescattering term, $\beta(\Theta, \lambda)$ and $\tau_{\text {ext }}(\lambda)$, are defined as functions of the volume size distribution of randomly oriented polydisperse spheroids (e.g. Dubovik et al., 2006):

$$
\begin{aligned}
& \beta(\Theta, \lambda)= \tau_{\text {scat }}(\lambda) P(\lambda, \Theta)=\int_{\ln \varepsilon_{\min }}^{\ln \varepsilon_{\max } \ln r_{\text {max }}} \frac{C_{\text {scat }}(\lambda, \Theta, n, k, \varepsilon, r)}{v(r)} \\
& \cdot \frac{d n(\varepsilon)}{d \ln (\varepsilon)} \frac{d V(r)}{d \ln r} d \ln r d \ln \varepsilon \\
& \tau_{\text {ext }}(\lambda)= \\
& \int_{\ln \varepsilon_{\min } \ln r_{\text {min }}}^{\ln \varepsilon_{\max } \ln r_{\text {max }}} \frac{C_{\text {ext }}(\lambda, n, k, \varepsilon, r)}{v(r)} \\
& \cdot \frac{d n(\varepsilon)}{d \ln (\varepsilon)} \frac{d V(r)}{d \ln r} d \ln r d \ln \varepsilon
\end{aligned}
$$

where $\varepsilon$ is the axis ratio of the spheroid and $r$ the radius of a volume-equivalent sphere (same volume as the spheroid); $\tau_{\text {scat }}$ and $\tau_{\text {ext }}$ are the scattering and extinction optical depths; $C_{\text {scat }}$ and $C_{\text {ext }}$ are the scattering and extinction cross sections; $n$ and $k$ are the real and imaginary parts of the refractive in$\operatorname{dex} ; v(r)$ is the volume of the particle with radius $r ; d V / d \ln r$ is the volume size distribution; and $d n(\varepsilon) / d \ln \varepsilon$ is the distribution of the spheroid axis ratios.

For computational convenience, the integration of Eqs. (3) and (4) can be approximated by using the kernel matrices $K_{\text {ext }}$ and $K_{\text {scat }}$ :

$$
\begin{aligned}
& \beta(\Theta, \lambda) \approx \sum_{p, s} \frac{d n\left(\varepsilon_{p}\right)}{d \ln \varepsilon} \frac{d V\left(r_{\mathrm{s}}\right)}{d \ln r} K_{\mathrm{scat}}\left(\Theta, \lambda, n, k, \varepsilon_{p}, r_{\mathrm{s}}\right) \\
& \tau_{\text {ext }}(\lambda) \approx \sum_{p, s} \frac{d n\left(\varepsilon_{p}\right)}{d \ln \varepsilon} \frac{d V\left(r_{\mathrm{s}}\right)}{d \ln r} K_{\mathrm{ext}}\left(\lambda, n, k, \varepsilon_{p}, r_{\mathrm{s}}\right)
\end{aligned}
$$

where $d n\left(\varepsilon_{p}\right) / d \ln \varepsilon$ and $d V\left(r_{\mathrm{s}}\right) / d \ln r$ are the values of the size distributions $d V(\varepsilon) / d \ln \varepsilon$ and $d V(r) / d \ln r$ given at discrete logarithmically equidistant points.

The kernels can be precomputed, and their dependence on $n$ and $k$ can be parameterized by a look-up table covering the range of expected values. The original SKYRAD.PACK code uses precalculated kernels for spherical particles for simulating particle scattering. However, for more accurate simulations of scattering by nonspherical particles, the modified inversion code utilised in this study uses the precalculated kernels for randomly oriented prolate and oblate spheroids instead of spheres (Olmo et al., 2008). For the calculation of the kernels for spheroids, the EBCM, or T-matrix theory (Waterman, 1971) has been used. Convergence procedures have been set so that phase matrix elements are calculated with an accuracy of $10^{-3}$; cross sections are accurate to within one part in $10^{4}$ (Mishchenko, 1993). The kernel matrices for randomly oriented prolate and oblate spheroids were calculated for 74 scattering angles, from 0 to $180^{\circ}$ using equiprobable distributions, following the recommendations of Dubovik et al. (2002a, 2006). These authors showed 
that using the assumption of an equal presence of prolate and oblate spheroids improves the retrieval stability. Actually, the kernel matrices used in the inversion method of Olmo et al. (2008) cover the following range of aerosol parameters:

$$
\begin{aligned}
& 1.33 \leq n \leq 1.6 \\
& 0.0005 \leq k \leq 0.64 \\
& 0.3 \leq \varepsilon \leq 3.0 \\
& 0.01 \leq x(=2 \pi \cdot r / \lambda) \leq 148.9 .
\end{aligned}
$$

Stable performance of the T-matrix code depends on $\varepsilon$ and $x$, and the T-matrix code becomes numerically unstable for spheroids with $\varepsilon \sim 2-2.4$ and size parameters $x$ larger than about 60 . This is a serious limitation of the precalculated kernel matrices used in the retrieval procedure proposed by Olmo et al. (2008). These limitations restrict the principal plan retrievals to the particle size range of 0.05 $\leq r \leq 7 \mu \mathrm{m}$ for $\lambda$ from 0.44 to $1.02 \mu \mathrm{m}$. Future improvements of the method used in this study using other methods such as the geometric-optics-integral-equation method (e.g. Yang and Liou, 1996) are needed to generate the kernel matrices of elongated and flattened spheroids for larger $x$.

In any case, the aerosol property retrievals used in this study were obtained during Saharan dust intrusions over Granada (far from Saharan dust sources). Therefore, dust particles with very large sizes are not expected to reach the study area due to the deposition processes during the long path way travelled by these particles. Thus, in spite of the inversion limitations, the aerosol properties used in this study are expected to be of reasonable accuracy.

For retrieving the effective columnar aerosol properties (size distribution, single scattering albedo and asymmetry parameter) by the principal plan inversion method, Eq. (3) is iteratively inverted, using as input $R(\Theta, \lambda), \tau_{a}(\lambda)$ and varying the refractive index to determine $\beta(\Theta, \lambda)$. The $R(\Theta, \lambda)$ and $\tau_{a}(\lambda)$ are derived from sun photometer experimental measurements. It is noted that $\tau_{a}(\lambda)$ is kept fixed in the iterative process. In each iteration the algorithm computes the effective volume size distribution, $V(r)$, by inversion of $\tau_{a}(\lambda)$ and $\beta(\Theta, \lambda)$, and uses this computed distribution to simulate $R^{\prime}(\Theta, \lambda)$, which is compared with the experimental $R(\Theta, \lambda)$ to evaluate the relative root mean square error (RMSE). For the initial guess in the iterative process the algorithm uses $\beta^{(1)}(\Theta, \lambda)=R(\Theta, \lambda)$. The process is repeated until the RMSE differences between measured and simulated normalized sky radiances and aerosol optical depths are less than $10 \%$ and $5 \%$, respectively. In this method the refractive index is assumed invariant with wavelength. The real part of the refractive index used in the iterative process is varied within the range $1.33-1.6$ in 0.02 steps, while the imaginary part is varied over the range $0-0.01$ in 0.0005 steps, covering the expected range of refractive indices for diverse aerosol mixtures (e.g. D'Almeida et al., 1991). The output of the retrieval a)

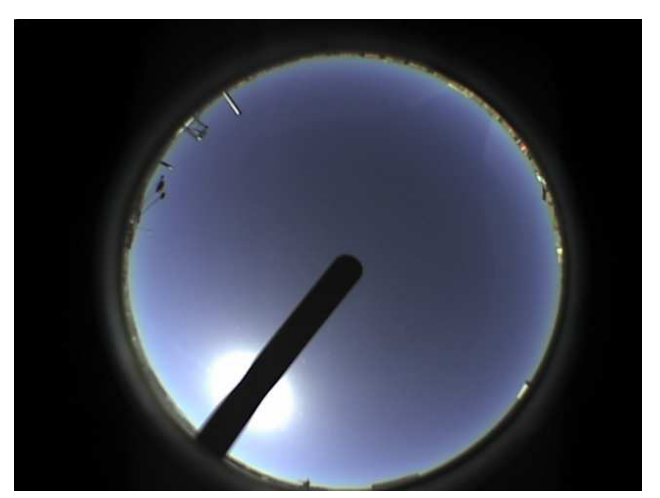

b)

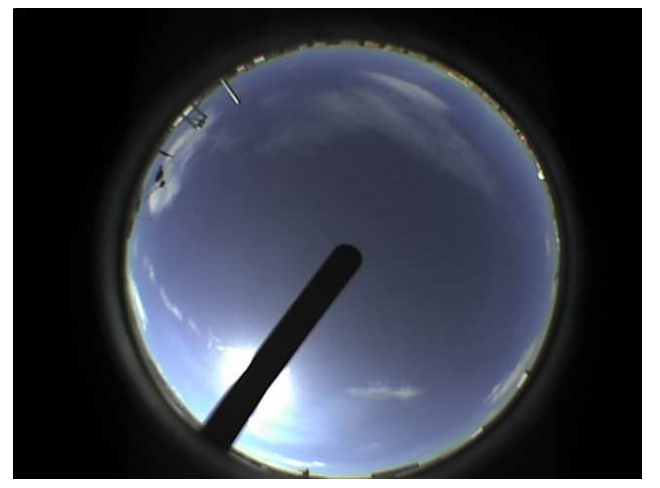

c)

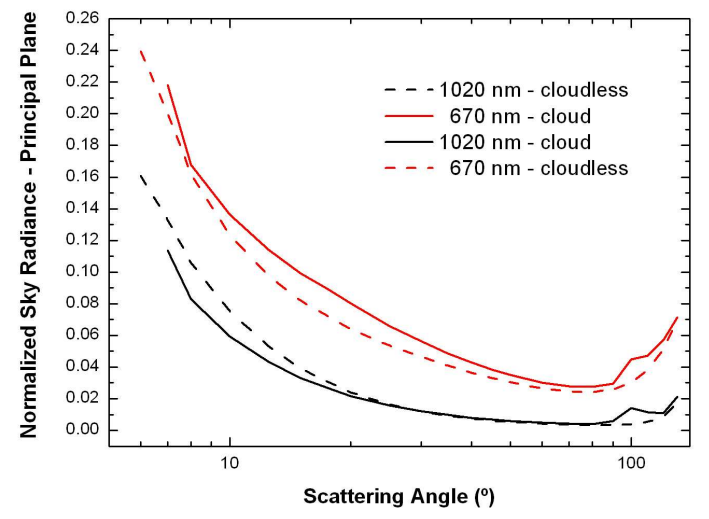

Fig. 1. All-sky image registered on: (a) 6 October 2010 at 10:15 h GMT: cloudless; (b) 7 October 2010 at 10:15 h GMT: clouds; and (c) normalized principal plane sky radiances at 670 and $1020 \mathrm{~nm}$ derived for the two situations.

algorithm includes the aerosol columnar size distribution, the refractive index, the single scattering albedo and asymmetry parameter for which the RMSE differences between measured and calculated radiances and aerosol optical depths are minimal. 

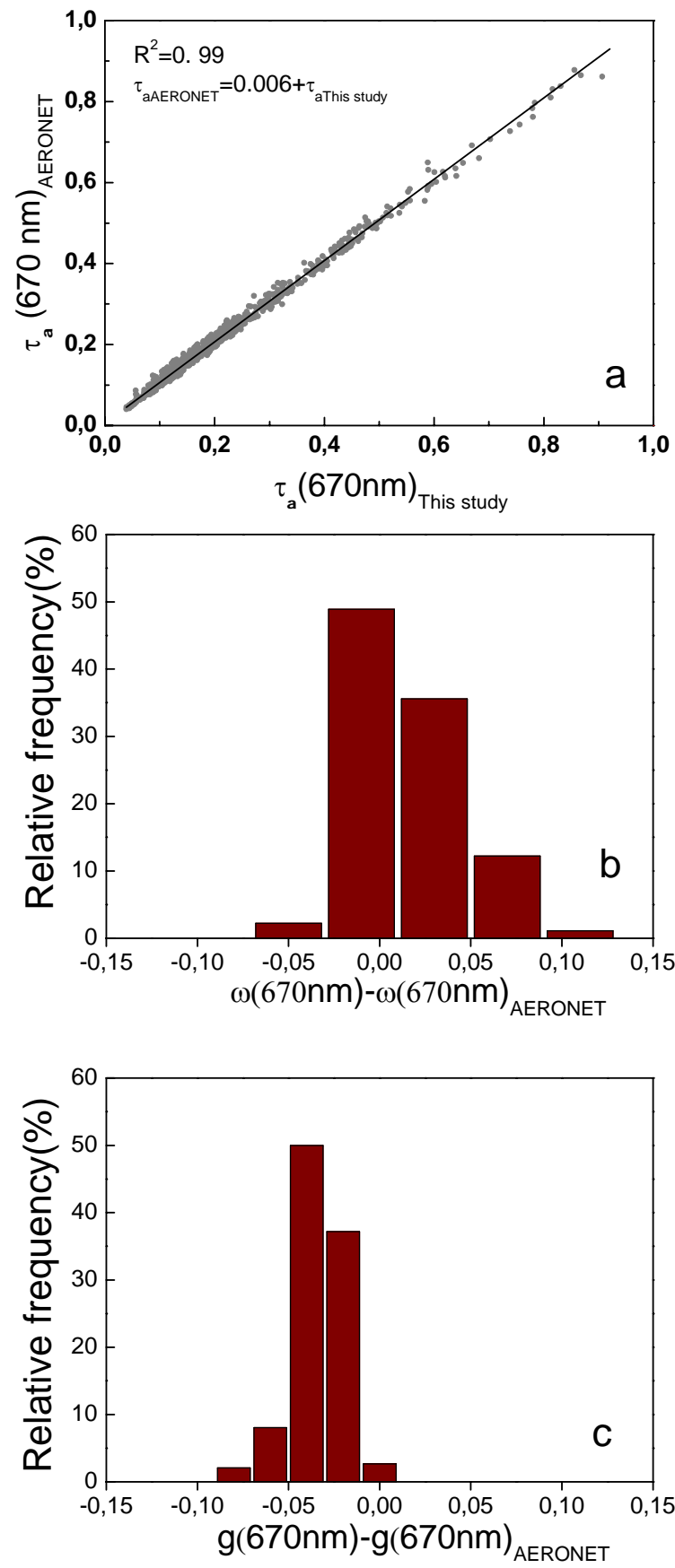

Fig. 2. (a) $\tau_{a}(670 \mathrm{~nm})$ provided by AERONET vs the data computed by our methodology. (b) and (c) Frequency distributions of the absolute differences between $\omega(670 \mathrm{~nm})$ and $g(670 \mathrm{~nm})$ provided by AERONET and computed by the Principal plane inversion algorithm.

In Appendix A we show the accuracy assessment of individual retrievals analyzed using this principal plane inversion method.
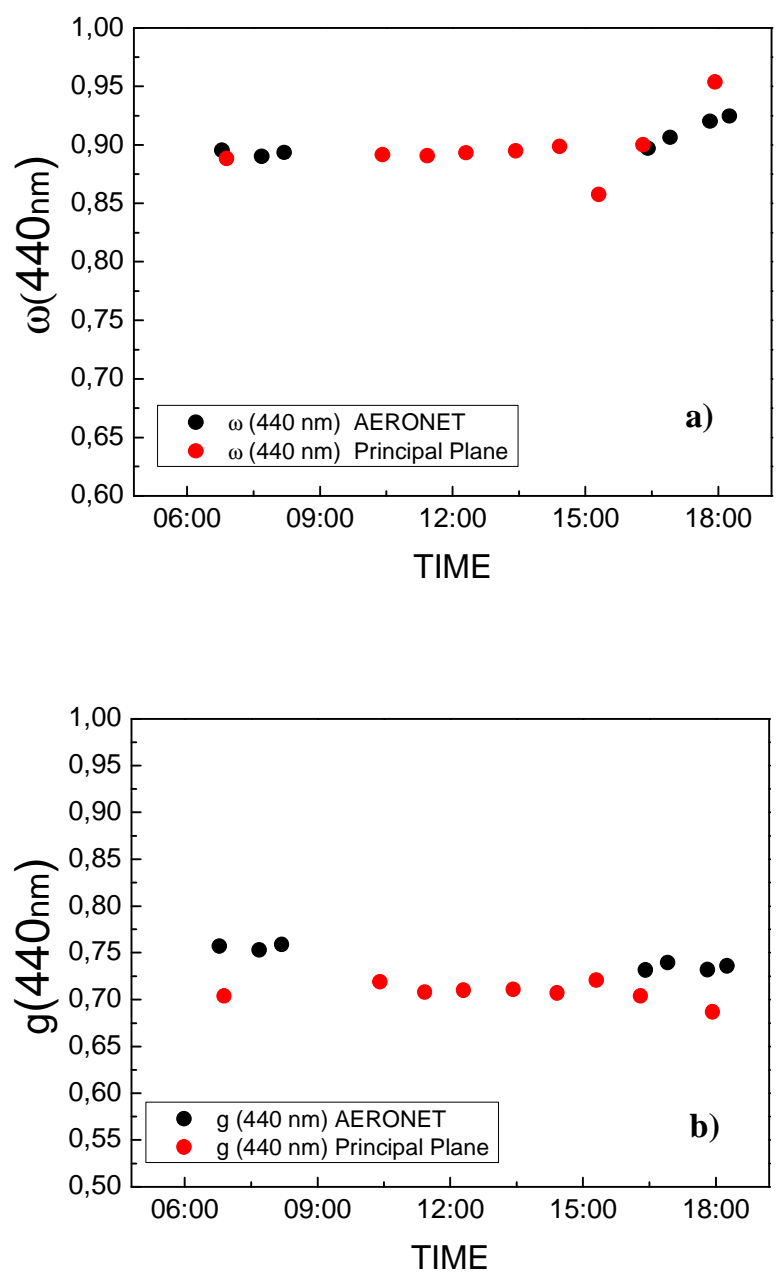

Fig. 3. (a) $\omega(440 \mathrm{~nm})$ and (b) $\mathrm{g}(440 \mathrm{~nm})$ evolutions derived by AERONET code (Level 2.0 data) and by the Principal plane inversion code at Granada (23 June 2008).

\subsection{Data quality control criteria}

Following the procedure proposed by Olmo et al. (2008), to eliminate cloud-contaminated aerosol optical depths, and the corresponding principal plane sky radiance measurements, first we applied the triplet stability criteria (Smirnov et al., 2000) to the spectral extinction data measured at the beginning of the principal plane scan. Even if data pass the threshold screening test, we take only data within three standard deviations of the mean in order to further reduce uncertainties induced by cloud contamination. In fact, high differences between two consecutive values of $\tau_{a}(\lambda)$ data are usually associated with passing clouds or aerosol inhomogeneities. In addition, the possible influence of thin clouds and spatially inhomogeneous clouds, which are difficult to completely eliminate and could contribute to the sky radiance errors, have been considered. Thus, we have obtained a smoothed principal plane sky radiance data set by applying a 
moving-average smoothing algorithm with a sliding window of five-point width. If the maximum difference between the smoothed and the initial sky radiances set (point to point) was higher than the threshold, $5 \%$ the data were rejected. Also, if the number of scattering angles in the measured sky radiance distributions was less than 20, the measurement record was eliminated. In addition, in order to accept a principal plane inversion as valid, the relative differences (residuals) between the measured and computed normalized sky radiances must be less than $10 \%$. Finally, to eliminate those cloud-contaminated sky radiances that passed the previous filters, we used a supervised inspection of sky images acquired with an All-Sky Imager (e.g. Cazorla et al., 2008). In this sense, the methodology is not completely automatic.

According to our experience, the cloud screening procedure presented above is very effective for removing cloudcontaminated data. For example, Fig. $1(a, b)$ shows the allsky images registered for two consecutive days at the same hour (6 October 2010 at 10:15 h GMT, representing a cloudless situation, and 7 October 2010 at 10:15 h, representing a cloudy condition). Also, Fig. 1c shows the evolution of the normalized principal plane sky radiances measured during these two situations. As can be seen on 7 October, there is an abrupt change in the spectral normalized sky radiance at scattering angles around $100^{\circ}$, which was associated with clouds (Fig. 1b). The normalized sky radiance data measured in this case were successfully identified as cloud-affected data by the cloud screening algorithm used in this work. As expected, sky radiance data measured on 6 October (cloudless case) passed this cloud screening procedure.

\subsection{Detection of desert dust days}

African dust intrusions over our study area during the period 2005-2010 have been confirmed by the CALIMA network (www.calima.ws). For detecting the African desert dust intrusions over the Iberian Peninsula, CALIMA uses the models SKIRON, BSC-DREAM, NAAPs and HYSPLIT4 backtrajectory analyses (Draxler et al., 2003), as well as synoptic meteorological charts, satellite images, and surface data (particulate matter recorded at air quality monitoring background stations). The air mass backward trajectories calculated by HYSPLIT were used to detect the source regions of desert dust observed over our study area during 2005-2010 by Valenzuela et al. (2012b). This method assumes that the dust particles are confined to the mixed layer at the potential source region, and that the air mass is loaded by desert dust when the air mass altitude is lower than or close to the altitude of the mixed layer at potential source. According to this criterion, three source regions were identified: (1) sector A (northern Morocco, northwestern Algeria) where the more frequent meteorological scenario favoring dust transport from this source was the low pressure over the Atlantic and high pressure systems over the Mediterranean Sea or northeastern Africa, (2) sector B (western Sahara, northwest- ern Mauritania and southwestern Algeria) where the desert dust transport was favored by a high pressure over the northern African continent, and (3) sector C (eastern Algeria, Tunisia) where the synoptic scenario favoring dust transport from this source was the low pressure over Morocco and high pressure over northeastern Africa. In the recent work of Valenzuela et al. (2012b), the aerosol optical and microphysical properties observed during desert dust intrusions over Granada 2005-2010 have been analyzed and classified according to desert dust origins. Summary statistics of daily mean aerosol optical properties obtained for each sector are shown in Table 1 . From this we can see that $\omega(\lambda)$ was slightly lower for sector A than the other two sectors.

\subsection{Validation of the retrieved aerosol optical properties}

The aerosol optical properties retrieved from principal plane measurements, using the algorithm proposed by Olmo et al. (2008), have been compared against the AERONET retrievals based on nearly coincident almucantar measurements.

Firstly, we compared the spectral aerosol optical depths computed in this work with those provided by AERONET (level 2.0). In this comparison, only $\tau_{a}(\lambda)$ data obtained during the desert dust events detected over Granada from 2005 to 2010 were used. Figure 2a shows the scatter plot of $\tau_{a}(670 \mathrm{~nm})$ data provided by AERONET versus those computed in this work. As can be seen, the $\tau_{a}(\lambda)$ data obtained by both methods are well-correlated with the coefficient of determination $\left(R^{2}\right)$ of 0.99 . The slope of the linear fit is equal to 1 and the intercept value is very small $(0.006)$. The mean absolute difference between the $\tau_{a}(670 \mathrm{~nm})$ computed in this work and that provided by AERONET is equal to 0.009 (Table 2). For $\tau_{a}(\lambda)$ at 440,870 and $1020 \mathrm{~nm}$ the mean absolute differences are $0.009,0.005$ and 0.009 , respectively (Table 2). Taking into account the uncertainty in $\tau_{a}(\lambda)$ computations (0.01), these results show good agreement between the $\tau_{a}(\lambda)$ computed by both methods.

Table 2 also shows the comparison between $\omega(\lambda)$ and $g(\lambda)$, retrieved by the principal plane inversion method of Olmo et al. (2008) and the AERONET almucantar inversion method during the desert dust intrusions observed at Granada from 2005 to 2010. In this comparison only nearly coincident measurements were used. On the other hand, only a small number of $\omega(\lambda)$ achieved the AERONET level 2.0 due to the limitations imposed by the AERONET inversion algorithm $\left(\tau_{a}(440 \mathrm{~nm})>0.4\right.$ and solar zenith angle $\left.>50^{\circ}\right)$. Thus, for comparing both data sets we used $\omega(\lambda)$ corresponding to AERONET level 1.5 (cloud screened data with pre- and postcalibrations applied) that fulfil the following conditions: $\tau_{a}$ $(440 \mathrm{~nm})>0.2$ and solar zenith angle $>50^{\circ}$. The uncertainty in the AERONET retrieval of $\omega(\lambda)$ is about \pm 0.03 for high aerosol loads $\left(\tau_{a}(440 \mathrm{~nm}) \geq 0.4\right)$ and solar zenith angles $>50^{\circ}$. For measurements with lower aerosol loading, the retrieval accuracy of $\omega(\lambda)$ significantly decreases because 
of the decrease of the information content, and the accuracy drops down to $0.05-0.07$ for $\tau_{a}(440 \mathrm{~nm}) \leq 0.2$ (Dubovik et al., 2000, 2002a).

Table 2 shows that the mean values of $\omega(\lambda)$ at 670 , 870 and $1020 \mathrm{~nm}$, retrieved by the principal plane inversion algorithm, are about 0.02 lower than those retrieved by AERONET. However, the mean single scattering albedo at $440 \mathrm{~nm}$ computed by the principal plane inversion is 0.01 larger than that provided by AERONET code. These differences are within the estimated error $(0.03-0.07)$ for $\omega(\lambda)$ (Dubovik et al., 2002). The root mean square error for $\omega(\lambda)$ ranges between 0.03 and 0.05 at 1020 and $440 \mathrm{~nm}$, respectively. Figure $2 b$, c show the absolute differences of $\omega(670 \mathrm{~nm})$ and $g(670 \mathrm{~nm})$ computed by our methodology versus AERONET. As can be seen, up to $70 \%$ and $80 \%$ of the absolute differences are within the estimated errors by AERONET $g(670 \mathrm{~nm})$ and $\omega(670 \mathrm{~nm})$, respectively. The root mean square error for $g(670 \mathrm{~nm})$ varies between 0.03 and 0.04 at 440 and $1020 \mathrm{~nm}$, respectively. In all channels the mean spectral asymmetry parameter computed using our method is smaller than that from AERONET (Table 2).

Figure 3 shows an example of the temporal evolutions of $\omega(440 \mathrm{~nm})$ and $g(440 \mathrm{~nm})$ computed by the two methodologies for June 23 (2008). The AERONET data are level 2.0 data. Taking into account the uncertainty in both optical parameters, Fig. 3 shows that $\omega(440 \mathrm{~nm})$ and $g(440 \mathrm{~nm})$ obtained by the two methods are comparable. The mean daily values ( \pm standard deviations) of $\omega(440 \mathrm{~nm})$ and $g(440 \mathrm{~nm})$ are $0.90 \pm 0.01$ and $0.74 \pm 0.01$ for the AERONET inversion code (almucantar configuration), and $0.89 \pm 0.02$ and $0.71 \pm 0.01$ for the principal plane code, respectively. The slight differences obtained are due to the different input parameters (almucantar and principal plane radiances), time measurements, different kernel matrices, as well as internal restrictions and convergence levels of both codes.

On the other hand, the sun photometer pointing errors (misalignments) can affect the principal plane measurements as well as the derived aerosol properties by the inversion methods (Torres, 2012). This author showed that these anomalies are significant for the largest errors and shortest scattering angles, showing lower $\omega(\lambda)$ values at noon (about $10 \%$ or more) while $\tau_{a}(\lambda)$ remain unchanged. In our results (Fig. 3) we observe no artifacts in the retrievals - due to the experimental pointing errors - like those shown by Torres (2012). Similar results are obtained for other days affected by high loads of Saharan dust particles at Granada (AERONET level 2.0 data).

\subsection{Aerosol radiative forcing}

Aerosol radiative forcing (ARF) at the surface (TOA) is defined as the instantaneous increase or decrease of the net radiation flux at the surface (TOA) that is due to an instantaneous change of aerosol atmospheric content. The atmo-
Table 1. The number of desert dust days, number of measurements recorded by sun photometer and the mean $\tau_{a}(\lambda), \omega(\lambda)$ and $g(\lambda)$ values for each sector $\mathrm{A}, \mathrm{B}$ and $\mathrm{C}$.

\begin{tabular}{lrrr}
\hline & Sector A & Sector B & Sector C \\
\cline { 2 - 4 } Days & 86 & 56 & 41 \\
Measurements & 426 & 287 & 195 \\
\hline$\tau_{a}(440 \mathrm{~nm})$ & $0.28 \pm 0.18$ & $0.30 \pm 0.13$ & $0.28 \pm 0.13$ \\
$\omega(440 \mathrm{~nm})$ & $0.89 \pm 0.03$ & $0.89 \pm 0.03$ & $0.90 \pm 0.03$ \\
$\omega(1020 \mathrm{~nm})$ & $0.90 \pm 0.03$ & $0.92 \pm 0.03$ & $0.92 \pm 0.03$ \\
$g(440 \mathrm{~nm})$ & $0.69 \pm 0.01$ & $0.70 \pm 0.0$ & $0.68 \pm 0.01$ \\
$g(1020 \mathrm{~nm})$ & $0.67 \pm 0.01$ & $0.67 \pm 0.01$ & $0.67 \pm 0.01$ \\
\hline
\end{tabular}

spheric ARF is defined as the radiative forcing at TOA minus the radiative forcing at the surface.

In this study, we have chosen the atmosphere without aerosols as the reference case. Thus, the instantaneous values of ARF can be derived from the following expression (Meloni et al., 2005):

$\mathrm{ARF}=\left(F^{\downarrow}-F^{\uparrow}\right)-\left(F_{0}^{\downarrow}-F_{0}^{\uparrow}\right)$

where $F$ and $F_{0}$ denote the global irradiances with aerosol and without aerosol, respectively. The arrows indicate the direction of the global irradiances (down and up).

To carry out instantaneous global solar irradiance computations, we have used the radiative transfer computer code SBDART (Ricchiazzi et al., 1998), which is a discrete ordinates radiative transfer model (Stamnes et al., 1988). This algorithm includes multiple scattering in a vertically inhomogeneous, nonisothermal plane-parallel media, and has been shown to be computationally efficient in reliably resolving the radiative transfer equation. This radiative transfer computer code characterizes atmospheric aerosol radiative effects using as input the solar zenith angle, the spectral aerosol optical depth, the spectral single scattering albedo, and the spectral asymmetry parameter. Logarithmic interpolation (or extrapolation for $\lambda<414 \mathrm{~nm}$ or $\lambda>860 \mathrm{~nm}$ ) was used to supply SBDART with aerosol optical depths, $\tau_{a}(\lambda)$ covering the entire wavelength range of the calculation (310$2800 \mathrm{~nm})$. Linear extrapolation is used for $\omega(\lambda)$ and $g(\lambda)$. In this study, we used the spectral aerosol optical depth, the spectral single scattering albedo, and the spectral asymmetry parameter obtained from the CIMEL sun photometer which were presented and analyzed in more detail by Valenzuela et al. (2012a,b). With respect to the vertical distribution of aerosol, we used the SBDART profile, which takes into account the aerosol-loaded atmosphere fitting an exponentialdecay to the aerosol optical depth derived by sun photometer. Input data include the total ozone column derived from the satellite Ozone Monitoring Instrument (OMI) and the surface spectral albedo provided by the AERONET algorithm, based on a dynamic spectral and spatial model estimation at four wavelengths: 440, 675, 870 and $1020 \mathrm{~nm}$. For land 
Table 2. Mean values ( \pm standard deviation) of spectral aerosol optical depth $\left(\tau_{a}(\lambda)\right)$, single scattering albedo $(\omega(\lambda))$ and asymmetry parameter $(g(\lambda))$; RMSE is the root mean square error and $\Delta$ refers to the absolute differences between retrievals obtained by our method and the AERONET code at 440,670, 870 and $1020 \mathrm{~nm}$ for all measurements nearly coincident in time during desert dust events from 2005 to 2010. Subscript " $a$ " and " $n$ " refers to AERONET and our method, respectively.

\begin{tabular}{lcccc}
\hline & $440 \mathrm{~nm}$ & $670 \mathrm{~nm}$ & $870 \mathrm{~nm}$ & $1020 \mathrm{~nm}$ \\
\hline$\tau_{a a}(\lambda)$ & $0.27 \pm 0.15$ & $0.22 \pm 0.15$ & $0.21 \pm 0.14$ & $0.20 \pm 0.13$ \\
$\tau_{a n}(\lambda)$ & $0.28 \pm 0.15$ & $0.23 \pm 0.14$ & $0.21 \pm 0.14$ & $0.20 \pm 0.13$ \\
$\omega_{a}(\lambda)$ & $0.89 \pm 0.03$ & $0.93 \pm 0.02$ & $0.94 \pm 0.02$ & $0.95 \pm 0.02$ \\
$\omega_{n}(\lambda)$ & $0.90 \pm 0.03$ & $0.91 \pm 0.03$ & $0.92 \pm 0.03$ & $0.93 \pm 0.03$ \\
$g_{a}(\lambda)$ & $0.72 \pm 0.02$ & $0.70 \pm 0.02$ & $0.70 \pm 0.02$ & $0.71 \pm 0.02$ \\
$g_{n}(\lambda)$ & $0.70 \pm 0.02$ & $0.67 \pm 0.02$ & $0.66 \pm 0.02$ & $0.67 \pm 0.02$ \\
$\operatorname{RMSE}\left(\tau_{a}(\lambda)\right)$ & 0.007 & 0.012 & 0.007 & 0.012 \\
$\operatorname{RMSE}(\omega(\lambda))$ & 0.048 & 0.034 & 0.028 & 0.026 \\
$\operatorname{RMSE}(g(\lambda))$ & 0.031 & 0.036 & 0.042 & 0.043 \\
$\Delta \tau_{a}(\lambda)$ & $0.009 \pm 0.008$ & $0.009 \pm 0.009$ & $0.005 \pm 0.006$ & $0.009 \pm 0.008$ \\
$\Delta \omega(\lambda)$ & $0.037 \pm 0.031$ & $0.027 \pm 0.021$ & $0.022 \pm 0.018$ & $0.021 \pm 0.016$ \\
$\Delta g(\lambda)$ & $0.026 \pm 0.017$ & $0.033 \pm 0.014$ & $0.039 \pm 0.015$ & $0.039 \pm 0.016$ \\
\hline
\end{tabular}

surface covers, the Lie-Ross model was adopted (Lucht and Roujean, 2000), considering the bidirectional reflectance distributions from MODIS (Moody et al., 2005). Mean values of surface spectral albedo of $0.05 \pm 0.04$ at $440 \mathrm{~nm}, 0.16 \pm 0.03$ at $675 \mathrm{~nm}, 0.31 \pm 0.04$ at $870 \mathrm{~nm}$ and $0.32 \pm 0.04$ at $1020 \mathrm{~nm}$ for the analyzed desert dust days were used in this work.

The parameters output by the code are the downward and upward global irradiance at surface and at TOA. Calculations were performed and integrated over the $0.31-2.8 \mu \mathrm{m}$ solar spectral range for solar zenith angles varying from $20^{\circ}$ to $80^{\circ}$.

Daily mean values of the aerosol radiative forcing at the surface (TOA) are derived from integration of the instantaneous aerosol radiative forcing at the surface (TOA), averaged 24 hours (Bush and Valero, 2003):

$\mathrm{DARF}=\int \frac{\mathrm{ARFdt}}{24}$.

The atmospheric heating rate was computed for each layer, based on finite difference estimates of the irradiance divergence at each pair of levels (Liou, 2002):

$\frac{\partial T}{\partial t}=\frac{g}{C_{p}} \frac{\Delta F_{\text {Atmosferic }}}{\Delta p}$

where $T$ is the temperature $(K), t$ is the time $(s), g$ is the gravitational acceleration $\left(9.8 \mathrm{~ms}^{-2}\right), C p$ is the specific heat of dry air $\left(\sim 1004 \mathrm{~J} \mathrm{~kg}^{-1} \mathrm{~K}^{-1}\right), F$ is the net all-wave flux $\left(\mathrm{W} \mathrm{m}^{-2}\right)$, and $p$ is the pressure $(\mathrm{Pa})$. In this study, we calculated the aerosol heating rate for the whole atmospheric column, which is the difference in heating rates between an aerosol-laden and an aerosol-free atmosphere.

\section{Results and discussion}

\subsection{Model output fluxes comparison against ground- based measurements and AERONET data}

Simulated net irradiances at the surface and TOA during desert dust intrusions at Granada (2005-2010) have been obtained from the SBDART radiative transfer model, using the experimental aerosol information (aerosol optical depth, single scattering albedo and asymmetry parameter) derived from the principal plane measurements as input. Additionally, net shortwave irradiances at the surface and TOA under a clean atmosphere (cloud-free conditions and absence of aerosol) have been derived from the SBDART code. Thus, a simulated ARF was calculated from Eq. (7) for the 911 instantaneous measurements obtained during desert dust events. As previously noted, the spectral aerosol optical properties used as input for the SBDART model calculations in this study were analyzed and classified in three groups according to the desert dust sources identified in Valenzuela et al. (2012b) (Table 1).

Firstly, the reliability of the SBDART model was analyzed. For that purpose, we compared the experimental downward irradiances and corresponding SBDART simulations for all desert dust cases analyzed in this study. Figure 4 shows three plots with the correlation between the measured and simulated values for the three desert dust origin sectors; sector A (northern Morocco, northwestern Algeria), sector B (western Sahara, northwestern Mauritania and southwestern Algeria) and sector C (eastern Algeria, Tunisia). The solid line represents the zero bias line (slope equal to one) which fits the data well, confirming the high degree of agreement. A linear regression analysis between the measured and modeled downward irradiances has been performed. The correlation coefficient values were higher than 0.98 , indicating that the 

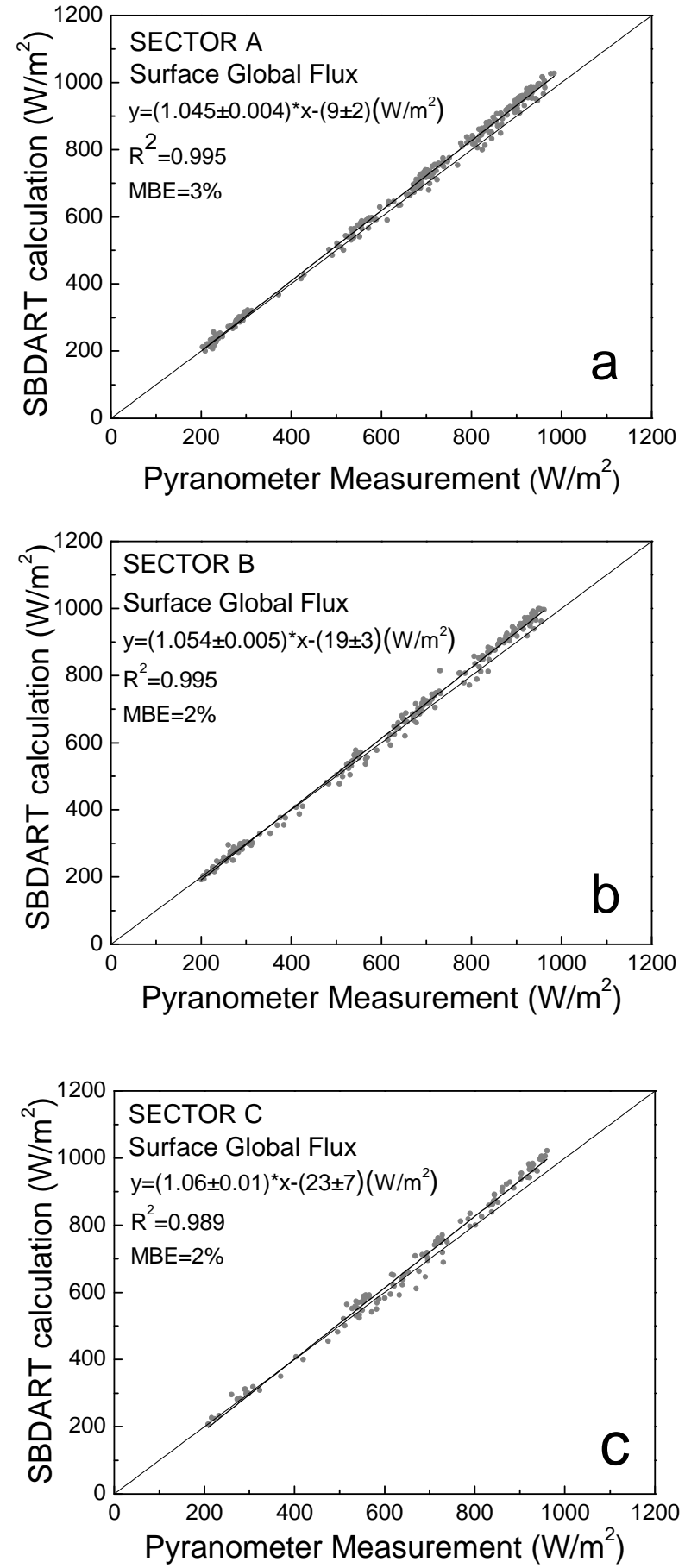

Fig. 4. Comparisons of surface global irradiance measurements obtained during desert dust events occurred at Granada during 20052010 with SBDART modeled results for (a) Sector A, (b) Sector B and (c) Sector C. The regression equations, determination coefficients and biases are included in these figures.

measured and modeled values were well correlated in the three dust origin classes. The statistical analysis gives slopes very close to unity, supporting the validity of the radiative transfer model computations of ARF presented in this work.

Figure 5 shows the relative differences between the experimental and modeled downward global irradiances $\left(F^{\text {mod }}-\right.$ $\left.F^{\exp } / F^{\exp }\right)$ as a function of the experimental values $\left(F^{\exp }\right)$. It can be seen that the SBDART code slightly overestimates the experimental global irradiance with most of the differences around $3 \%$, indicating the reliability of the radiative transfer model used in this work for the ARF calculations. The mean values of these relative differences are $+3 \%$, $+2 \%$ and $+2 \%$ for sectors A, B and C, respectively. These small discrepancies between modeled and experimental values could be associated with errors in the model input parameters as well as errors in the experimental measurements of the global irradiance. Additionally, these differences could be partially related to the overestimation of the diffuse component by the SBDART model (Pinker et al., 2010; Won et al., 2004; Kim et al., 2005).

The SBDART simulations of instantaneous direct, diffuse and net global irradiances at the surface for desert dust intrusions over Granada during 2005-2010 for the three desert dust origin classes have been obtained. In addition, the corresponding simulated surface irradiances for aerosolfree conditions for these three classes were calculated. In aerosol-free conditions the calculated mean net global irradiances at surface were $\sim 700 \pm 250 \mathrm{~W} \mathrm{~m}^{-2}$ for sector $\mathrm{A}$ and $\sim 690 \pm 250 \mathrm{~W} \mathrm{~m}^{-2}$ for sectors B and C. During African dust intrusions, the mean values were of $650 \pm 250 \mathrm{~W} \mathrm{~m}^{-2}$, $640 \pm 250 \mathrm{~W} \mathrm{~m}^{-2}$ and $650 \pm 230 \mathrm{~W} \mathrm{~m}^{-2}$ for sectors A, B and $\mathrm{C}$, respectively. This means that desert dust events over the study location caused an average decrease in the net global solar radiation at surface of $7.1 \%$ (sector A), $7.7 \%$ (B), and $6.6 \%(\mathrm{C})$, which means less energy reaching the ground and, therefore, more surface cooling. This decrease in the net global radiation was due to the balance between the strong increases in the diffuse irradiance around $250 \%$ and the substantial reduction of the direct irradiance around $26 \%$. The diffuse irradiance ranged from $\sim 50 \mathrm{~W} \mathrm{~m}^{-2}$ in aerosol-free conditions to $175-194 \mathrm{~W} \mathrm{~m}^{-2}$ in desert dust conditions for the three sectors. The direct irradiance ranged from $\sim 645$ $653 \mathrm{~W} \mathrm{~m}^{-2}$ in aerosol-free conditions to $447-478 \mathrm{~W} \mathrm{~m}^{-2}$ in desert dust conditions for the three sectors. These large changes in direct and diffuse irradiances highlight the importance of desert dust intrusions over southeastern Spain, indicating that these type of particles significantly affect the propagation of solar radiation through the atmosphere. We have also computed mean values of the upward radiation at TOA for desert dust intrusions and for the corresponding aerosol-free conditions. The desert dust particles produced an increase in the upward radiation of $8.2 \%, 10.3 \%$ and $9.4 \%$ for sectors $\mathrm{A}, \mathrm{B}$ and $\mathrm{C}$ respectively. These results reveal that desert dust particles cause significant planetary cooling.

Aerosol radiative forcing (ARF) cannot be directly validated against AERONET measurements, considering the 
methodological differences (Garcia et al., 2011). This comparison can be only indirectly and partly achieved, through validation of ARF components $\left(F^{\downarrow}\right.$ at surface and $F^{\uparrow}$ at TOA) (Fig. 6). Considering that AERONET determines instantaneous global irradiances in the spectral range from 0.2 to $4.0 \mu \mathrm{m}$, we have run the SBDART model again considering this spectral range. The comparison of the downward instantaneous global irradiances at the surface corresponding to both data sets were in good agreement, as can be seen from the regression fit and the coefficient of determination. Nevertheless, there was a small relative difference of $1 \%$ and $2.4 \%$ between upward global irradiances at TOA and downward global irradiances at the surface, respectively. These small differences between the SBDART output and AERONET irradiance data could be due to the small differences in the input data.

In any case the good agreement between AERONET and SBDART irradiances suggests that the aerosol optical properties used as input in this work appropriately represent aerosol properties during desert dust outbreaks over our study area.

\subsection{Aerosol radiative forcing and aerosol radiative forcing efficiency during desert dust events}

\subsubsection{Annual evolution of aerosol radiative forcing}

The overall mean daily ARF at TOA during all desert dust events was $(-6 \pm 5) \mathrm{W} \mathrm{m}^{-2}$, while the overall mean daily ARF at surface was $(-20 \pm 11) \mathrm{W} \mathrm{m}^{-2}$, producing an atmospheric mean daily ARF value of $(+14 \pm 8) \mathrm{W} \mathrm{m}^{-2}$. Considering only the aerosol effect, this situation produced a mean aerosol heating rate of $0.13 \pm 0.07 \mathrm{~K}$ per day, for the entire atmospheric column, during desert dust events. The negative daily ARF value at TOA indicates that desert dust aerosol increased light scattered back to space, inducing thus a significant cooling of the Earth's atmosphere. In addition, the negative value at the surface reveals that the desert dust aerosol significantly reduces the solar radiation reaching the ground level, thus producing a large surface cooling. This result suggests a relevant absorption of solar radiation in the atmosphere, leading to significant atmospheric warming.

The monthly mean values of daily ARF at the surface, TOA and atmosphere during all desert dust events occurred at Granada from 2005 to 2010 are shown in Fig. 7a. Additionally, the $\tau_{a}(440 \mathrm{~nm})$ and $\omega(\lambda)$ at $440 \mathrm{~nm}$ and $1020 \mathrm{~nm}$ are shown in Fig. 7b. The month of April had the largest mean $\tau_{a}(440 \mathrm{~nm})$ value $(0.56 \pm 0.25)$ followed by May $(0.31 \pm 0.14)$, July $(0.32 \pm 0.16)$, June $(0.29 \pm 0.14)$ and September $(0.29 \pm 0.20)$. The lowest mean $\tau_{a}(440 \mathrm{~nm})$ value corresponded to October $(0.23 \pm 0.17)$. Daily ARF values ranged from $-13 \pm 8 \mathrm{~W} \mathrm{~m}^{-2}$ to $-34 \pm 15 \mathrm{~W} \mathrm{~m}^{-2}$ at surface, from $-4 \pm 3 \mathrm{~W} \mathrm{~m}^{-2}$ to $-13 \pm 7 \mathrm{~W} \mathrm{~m}^{-2}$ at TOA this being a change from $+6 \pm 4 \mathrm{~W} \mathrm{~m}^{-2}$ to $+21 \pm 12 \mathrm{~W} \mathrm{~m}^{-2}$ in the atmosphere, and the corresponding aerosol atmospheric

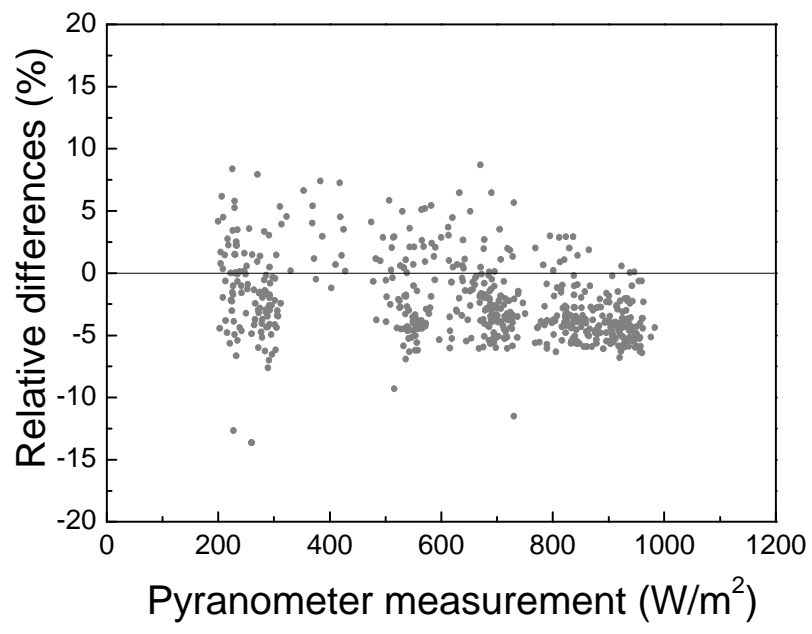

Fig. 5. Relative differences between modeled (SBDART) and experimental (CM-11) downward irradiances against experimental values.

heating rates, for the entire atmospheric column, from $0.05 \pm 0.04 \mathrm{Kday}^{-1}$ to $0.19 \pm 0.10 \mathrm{Kday}^{-1}$. The monthly mean ARF value at surface was larger in warm seasons with a maximum in April. It is important to note that the monthly evolution of the ARF at surface follows the monthly evolution of the aerosol optical depth found by Valenzuela et al. (2012a). However, the relationship between the monthly evolution of the ARF at TOA and the monthly evolution of $\tau_{a}(\lambda)$ is not clear. This behavior could be attributed to effects induced by other aerosol properties such as single scattering albedo. The typical $\omega(\lambda)$ increase in wavelength for desert dust particles occurred in all months except September and October. However, during warm seasons the monthly mean $\omega(\lambda)$ value decreased in all wavelengths with respect to other seasons. In fact, the lowest values of daily ARF at TOA corresponded to the lowest monthly values of the single scattering albedo for those months (Valenzuela et al., 2012a). This result is in agreement with the works of Di Biagio et al. (2009) and Antón et al. (2011) who showed that the single scattering albedo has a large influence on the daily ARF. The small values of the forcing at TOA during those months and the corresponding high values at the surface mean that less solar energy reached the ground and more energy was absorbed by atmosphere. For this reason, the atmospheric daily ARF was higher from April to September than the rest of months.

\subsubsection{Aerosol radiative forcing by desert dust origin sectors}

As noted in the methodology section, the aerosol optical and microphysical properties have been analyzed and classified during dust events over Granada according to the desert dust sources. These instantaneous optical properties have been 

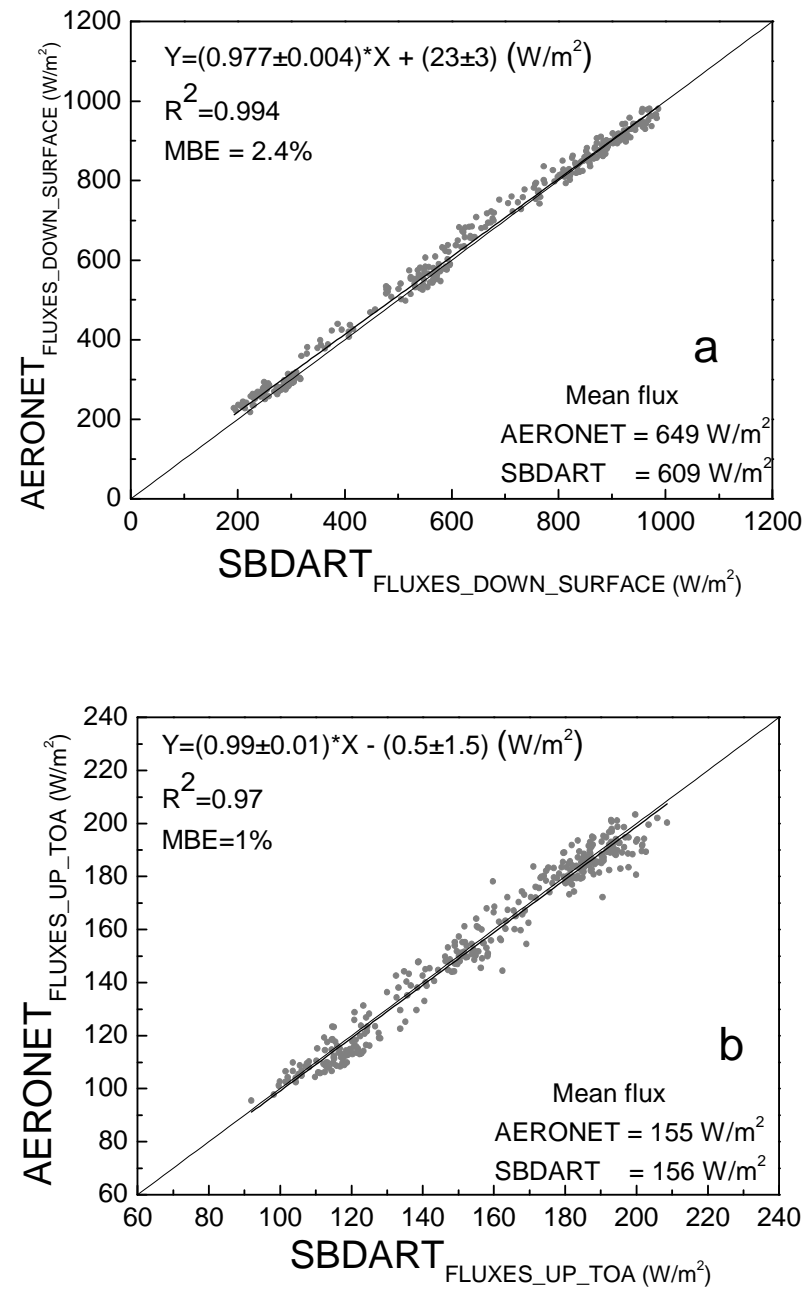

Fig. 6. Scatter plots of the instantaneous global irradiances using SBDART model against corresponding AERONET fluxes for (a) downward fluxes at surface and (b) upward fluxes at TOA. The black lines are the linear fits. The regression equations, determination coefficients and biases are included in these figures.

used as inputs to the SBDART model to derive the aerosol radiative forcing for each desert dust origin sector.

Firstly, we have studied the dependence of aerosol radiative forcing on solar zenith angle (SZA) for each sector. Figure 8 shows the ARF at surface and TOA for each class as a function of SZA. For all SZA, there are small differences in ARF at TOA between the three sectors. From this figure, the dependence of the ARF on SZA at TOA is obvious. As the solar zenith angle increases, the ARF at TOA tends to increase (in absolute value) up to a SZA of $70^{\circ}$, since part of the scattered light goes back to space, even with predominant forward scattering. In contrast, the ARF at surface only presents a slight SZA dependence. The ARF at surface for the three sector increases slightly (absolute value) up to a SZA of $70^{\circ}$. This is due to the increase in photon path length
Table 3. The $p$ values of the Kolmogorov-Smirnov statistical test applied to ARF at surface and TOA data for each pair of origin sectors. The $p$ values above the diagonal, for each pair of data, correspond to the daily ARF at TOA, while the values below the diagonal correspond to the daily ARF at surface. Values of $p<0.05$ indicate statistical significant differences between the means at the $95 \%$ confidence level.

\begin{tabular}{|c|c|c|c|}
\hline & Sector A & Sector B & Sector C \\
\hline & \multicolumn{3}{|c|}{ Daily ARF at TOA } \\
\hline Sector A & & 0.008 & 0.009 \\
\hline Sector B & 0.493 & & 0.601 \\
\hline \multirow[t]{2}{*}{ Sector C } & 0.555 & 0.084 & \\
\hline & \multicolumn{3}{|c|}{ Daily ARF at surface } \\
\hline
\end{tabular}

and the associated increase in the attenuation, scattering and absorption, of direct solar radiation (Meloni et al., 2005). For SZA larger than $70^{\circ}$, the ARF at surface and TOA decrease (in absolute value) because the slant path is no longer optically thin (Boucher at al., 1998). Additionally, it can be seen that the ARF at surface presents larger values (in absolute term) when air masses are transported from sector B. This is consistent with higher value of $\tau_{a}$ obtained for this sector (Table 1).

Considering interest from a climatic point of view, we have computed the daily average of the ARF (Eq. 8). Thus, mean ARF values at surface (TOA) were $-20 \pm 12$ $(-5 \pm 5) \mathrm{W} \mathrm{m}^{-2},-21 \pm 9(-7 \pm 5) \mathrm{W} \mathrm{m}^{-2}$ and $-18 \pm 9$ $(-6 \pm 5) \mathrm{W} \mathrm{m}^{-2}$ for sectors $\mathrm{A}, \mathrm{B}$ and $\mathrm{C}$, respectively. The mean ARF values at the surface and TOA for the different desert dust origin sectors were within the standard deviations, so there are no significant differences among them. The atmospheric mean ARF ranged between $15 \pm 9 \mathrm{~W} \mathrm{~m}^{-2}$, $14 \pm 7 \mathrm{~W} \mathrm{~m}^{-2}$ to $12 \pm 8 \mathrm{~W} \mathrm{~m}^{-2}$ for sectors $\mathrm{A}, \mathrm{B}$ and $\mathrm{C}$, respectively. The mean aerosol heating rate $\left(\mathrm{Kday}^{-1}\right)$ for the entire atmospheric column was $0.14 \pm 0.08 \mathrm{~K} \mathrm{day}^{-1}$, $0.13 \pm 0.06 \mathrm{~K} \mathrm{day}^{-1}$ and $0.11 \pm 0.07 \mathrm{~K} \mathrm{day}^{-1}$ for sector $\mathrm{A}$, sector $\mathrm{B}$ and sector $\mathrm{C}$, respectively. The slightly larger mean aerosol heating rate for sector A was attributed to high atmospheric absorption when air masses were transported from this sector. To corroborate possible differences between daily mean ARF values from these sectors, a nonparametric statistical-significance test (Kolmogorov-Smirnov) was applied to the data. This test revealed, at a $95 \%$ confidence level, which sectors were statistically different (Table 3 ). The values above the diagonal, for each pair of desert dust sources, indicate the $p$ value of the test with respect to the daily ARF at TOA, while the values below the diagonal correspond to the daily ARF at surface. If $p<0.05$,the difference in daily ARF was significant. The test revealed that differences in daily ARF at TOA for sector A were significant with respect to sectors B and C. However, these two last sectors did not show significant differences. Additionally, the 

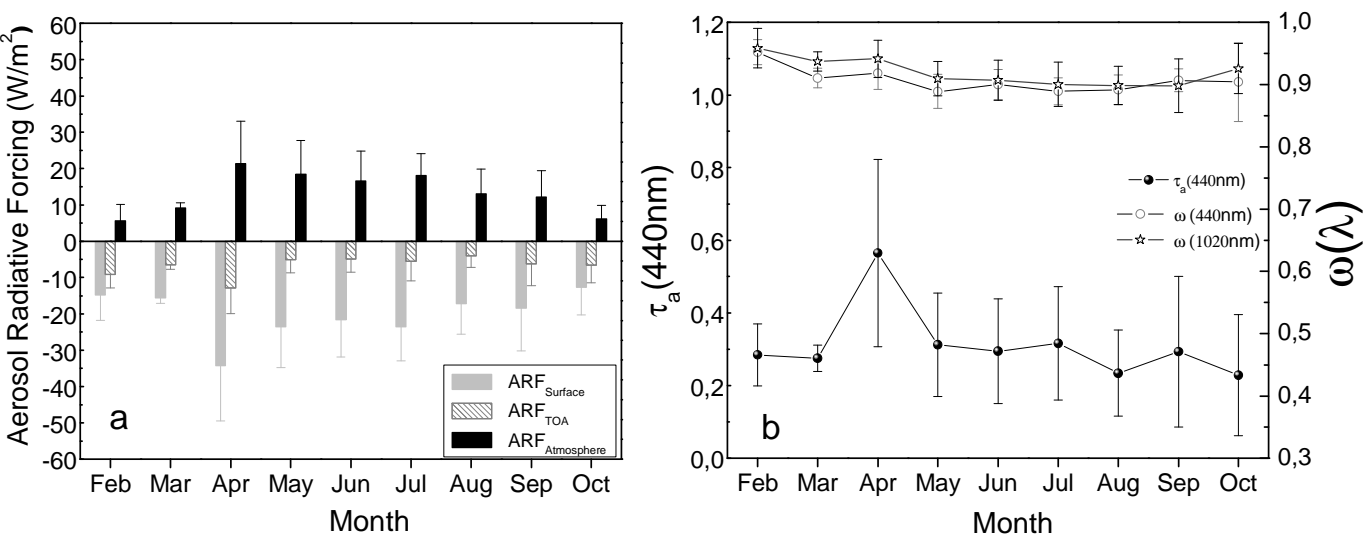

Fig. 7. (a) Monthly mean values of aerosol radiative forcing at TOA, surface and in the atmosphere during desert dust events at Granada during 2005-2010. (b) Monthly mean aerosol optical depth at $440 \mathrm{~nm}$ and single scattering albedo at $440 \mathrm{~nm}$ and $1020 \mathrm{~nm}$. The error bars correspond to standard deviation

Table 4. Daily aerosol radiative forcing $\left(\mathrm{W} \mathrm{m}^{-2}\right)$ and daily aerosol radiative forcing efficiency $\left(\mathrm{W} \mathrm{m}^{-2}\right)$ at surface, TOA and in the atmosphere observed over different locations during desert dust events. The second column $(\lambda)$ indicates the spectral range considered and third column shows the surface albedo (A) used in each study.

\begin{tabular}{|c|c|c|c|c|c|c|c|c|}
\hline Reference & $\lambda(\mathrm{mm})$ & A & ARF TOA & ARF Surface & ARF Atmosphere & ARFE TOA & ARFE Surface & Location \\
\hline Meloni et al. (2005) ${ }^{1}$ & $0.4-0.7$ & $0.02-0.37$ & -5.1 to -8.7 & -11.0 to -14.2 & 3.7 to 9 & -15.0 to -16.4 & -28.4 to -30.1 & Lampedusa, Italy \\
\hline Derimian et al. (2006) ${ }^{2}$ & $0.175-2.270$ & $0.23-0.35$ & -2.1 & -6.4 & - & -22 & -65 & Negev, Israel \\
\hline Derimian et al. $(2008)^{3}$ & $0.2-4.0$ & spectral depen. & -8.1 & -29.1 & 21.0 & -15.7 & -56.4 & M'Bour, Senegal \\
\hline Prasad et al. (2007) ${ }^{4}$ & $0.3-3.0$ & 0.25 & -2.9 to -26 & -29.5 to -87.5 & - & $-17 \pm 3$ & $-46 \pm 3$ & Kanpur, India \\
\hline Lyamani et al. (2006) ${ }^{5}$ & $0.4-0.7$ & 0.15 & -4.0 & -20.4 & 16.4 & -14.5 & -73.4 & Granada, Spain \\
\hline Di Sarra et al. (2011) ${ }^{6}$ & $0.3-3.0$ & 0.07 & - & $-69.9 \pm 3.4$ & - & - & $-59.9 \pm 2.6$ & Lampedusa, Italy \\
\hline Huang et al. (2009) ${ }^{7}$ & $0.175-4.0$ & spectral depen. & 14.11 & -64.72 & 78.8 & - & - & Taklimakan Desert China \\
\hline Saha et al. $(2008)^{8}$ & $0.28-2.8$ & spectral depen. & -7.7 to -9.8 & -61.8 to -64.4 & 54.1 to 54.6 & -9.7 to -12.4 & -78.2 to -81.5 & Toulon, France \\
\hline Present study & $0.31-2.8$ & spectral depen. & $-5 \pm 5$ & $-20 \pm 12$ & $15 \pm 9$ & $-17 \pm 7$ & $-74 \pm 12$ & Granada, Spain \\
\hline Present study & $0.31-2.8$ & spectral depen. & $-7 \pm 5$ & $-21 \pm 9$ & $14 \pm 7$ & $-20 \pm 9$ & $-70 \pm 14$ & Granada, Spain \\
\hline Present study & $0.31-2.8$ & spectral depen. & $-6 \pm 5$ & $-18 \pm 9$ & $12 \pm 8$ & $-22 \pm 10$ & $-65 \pm 16$ & Granada, Spain \\
\hline
\end{tabular}

Method: ${ }^{1}$ Surface albedo varies between 0.02 at $20^{\circ}$ and 0.37 at $90^{\circ}$ SZA. ${ }^{2}$ Mixture of desert dust and anthropogenic aerosol. ${ }^{3}$ Takes into account the nonsphericity of dust particles for simulating radiative effects. ${ }^{4}$ The $\omega(\lambda)$ (coarse mode) was found to increase with the arrival of dust storms and have a pronounced effect at higher wavelengths. ${ }^{5}$ Fixed surface albedo of 0.15 . ${ }^{6}$ Surface albedo has been calculated as the weighted average of land and ocean albedo over a $10 \mathrm{~km}$ diameter area around the measurement site. ${ }^{7}$ Takes into account the vertical distributions of the dust aerosol extinction coefficient. ${ }^{8}$ The single scattering albedo at $525 \mathrm{~nm}$ ranged between 0.7 and 0.8 , indicating significant absorption.

test revealed the absence of significant differences in daily ARF at surface between the three different origin sectors. A possible explanation for this result could be the different single scattering albedo between sector $\mathrm{A}$ and the other sectors and its great influence on the daily ARF at TOA.

Uncertainties in our daily ARF computation may be related to uncertainties in the retrieval of optical variables, $\tau_{a}$ $(\lambda), \omega(\lambda)$ and $g(\lambda)$. The sensitivity analysis performed by Pandithurai et al. (2008) using the SBDART model showed that an error of 0.02 in $\tau_{a}(\lambda)$ and in $\omega(\lambda)$ could result in an uncertainty of 1.5 and $3.0 \mathrm{~W} \mathrm{~m}^{-2}$, respectively, in daily ARF at the surface. The corresponding errors in daily ARF at TOA would be 0.5 and $1.6 \mathrm{~W} \mathrm{~m}^{-2}$, respectively. Another error source could be the uncertainties related to the considered spectral surface albedo and uncertainties in meteorological parameter considered by the radiative transfer model.
The overall uncertainty in the estimated daily ARF due to deviations in simulation was found in the range $~ 10-15 \%$ (Prasad et al., 2007; Alam et al., 2012).

The daily aerosol radiative forcing efficiency (ARFE), calculated as daily aerosol radiative forcing per unit of $\tau_{a}(440 \mathrm{~nm})$, was also investigated in this study. Thus, we have computed daily aerosol radiative forcing efficiency (ARFE) as the ratio of daily aerosol radiative forcing by the corresponding daily mean $\tau_{a}(440 \mathrm{~nm})$. Using these daily $A R F E$ we also computed the ARFE for each desert dust sector. The mean ARFE values at the surface showed a maximum (absolute value) for sector $\mathrm{A}\left(-74 \pm 12 \mathrm{~W} \mathrm{~m}^{-2}\right)$, a minimum (absolute value) for sector $\mathrm{C}\left(-65 \pm 16 \mathrm{~W} \mathrm{~m}^{-2}\right)$ and an intermediate value for sector $\mathrm{B}\left(-70 \pm 14 \mathrm{~W} \mathrm{~m}^{-2}\right)$. These mean ARFE values at the surface indicated that the surface was deprived of a substantial amount of solar 


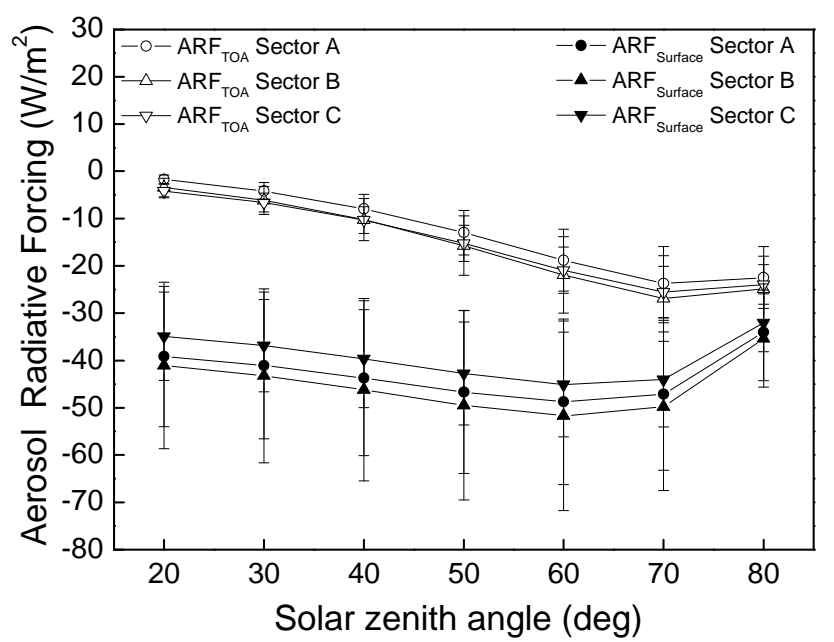

Fig. 8. Computed aerosol radiative forcing at TOA (open symbols) and at surface (full symbols) as a function of solar zenith angle for the sectors $\mathrm{A}, \mathrm{B}$ and $\mathrm{C}$ during desert dust events occurred at Granada from 2005 to 2010 . The error bars correspond to standard deviation.

energy in the presence of African desert dust over southeastern Spain. Figure 9a shows the monthly mean values of the ARFE at the surface according to the classification of the desert dust origin sources. ARFE at the surface was larger in warm seasons for three sectors with maxima of $-80 \pm 13 \mathrm{~W} \mathrm{~m}^{-2}$ for both sector $\mathrm{C}$ in May and sector A in July. The minimum values were of $-54 \pm 5 \mathrm{~W} \mathrm{~m}^{-2}$ and $-47 \pm 14 \mathrm{~W} \mathrm{~m}^{-2}$ for sectors B and C in March and February, respectively. The high load of mineral particles and higher likelihood of desert dust intrusions during warm months could explain higher ARFE at our site when air masses were transported from any of the three desert dust origin sources. Additionally, the daily ARFE values at TOA ranged from a mean $-17 \pm 7 \mathrm{~W} \mathrm{~m}^{-2}$ (sector A) to $-22 \pm 10 \mathrm{~W} \mathrm{~m}^{-2}$ (sector C), again with an intermediate value of $-20 \pm 9 \mathrm{~W} \mathrm{~m}^{-2}$ for sector B. The mean ARFE values obtained in sector A (slightly lower absolute value at the TOA and higher absolute value at the surface) could be explained by the lowest single scattering albedo in this sector. Monthly evolution of the ARFE at TOA (Fig. 9b) did not show important differences between the three origin sources. In fact, we have found that during warm seasons, ARFE was lower than for other months in all three sectors. In warm months we found lower single scattering albedo values for the three sectors.

\subsubsection{Comparison with other data sets}

It is interesting to compare our results with those obtained during desert dust events in other regions. In Table 4, we present the daily ARF and daily ARFE values given by several authors for situations dominated by desert dust, and for cases where dust is mixed with other aerosol types. Daily ARF values ranged from $-2.1 \mathrm{~W} \mathrm{~m}^{-2}$
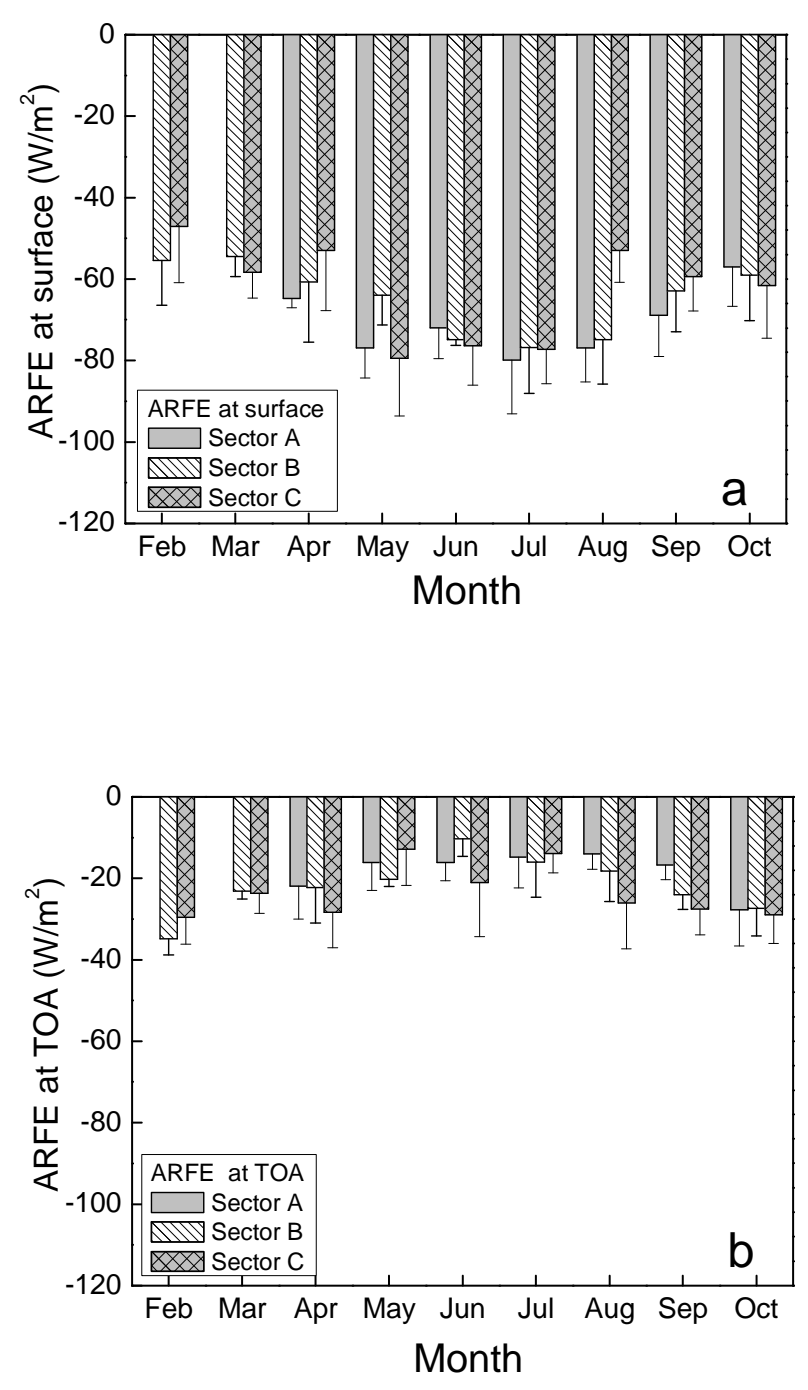

Fig. 9. Monthly mean values of aerosol radiative forcing efficiency (ARFE) according to the classification by origin sources during desert dust events occurred at Granada during 2005-2010, (a) at surface and (b) at TOA. The error bars correspond to standard deviation.

(Negev, Israel) to $-26 \mathrm{~W} \mathrm{~m}^{-2}$ (Kanpur, India) at TOA, from $-6.4 \mathrm{~W} \mathrm{~m}^{-2}$ (Negev, Israel) to $-87.5 \mathrm{~W} \mathrm{~m}^{-2}$ (Kanpur, India) at the surface, and from $\sim 4 \mathrm{~W} \mathrm{~m}^{-2}$ (Lampedusa) to $\sim 78.8 \mathrm{~W} \mathrm{~m}^{-2}$ (Taklimakan Desert, China) in the atmosphere. The results of the comparisons of the ARF and ARFE showed that the values obtained in our study were within the range reported by other authors during desert events. The differences may likely be related to the differences in the methods used, measurement periods, desert dust load, chemical composition of dust, aerosol mixing state and surface albedo. Additionally, the right characterization of the surface albedo is a crucial issue to evaluate the aerosol radiative forcing (Myhre et al., 2003). However, few studies have taken into account the spectral dependence of surface albedo, with 
many studies using a fixed value of this variable which makes intercomparison difficult.

Daily ARFE differences presented in Table 4, mainly at TOA, could be due to stronger dependence on surface albedo and $\omega(\lambda)$. The high daily ARFE values at the surface obtained during desert dust events over at Granada could be explained in terms of significant contributions of anthropogenic pollutants (especially absorbing particles). In fact, Valenzuela et al. (2012a) reported values of $\omega(\lambda)(0.89$ at $440 \mathrm{~nm})$ during these desert dust events which are lower than those reported in the literature for desert dust aerosols (e.g. Dubovik et al., 2002b). However, single scattering albedos obtained in our study were comparable to those obtained at the Mediterranean sites by other authors. For instance, Perrone and Bergamo (2011) showed that the contribution of anthropogenic particles can be relevant during desert dust events. These authors reported $\omega(\lambda)$ values at $550 \mathrm{~nm}$ in the range $0.87-0.95$ at Lecce $\left(40.33^{\circ} \mathrm{N}, 18.10^{\circ} \mathrm{E}\right)$ in the Central Mediterranean during desert dust events.

\section{Conclusions}

In this study we evaluated the aerosol radiative forcing (ARF) at the surface and TOA during desert dust events over Granada (southeastern Spain) from 2005 to 2010 at temporal scales from daily to seasonal. In addition, the aerosol radiative forcing efficiency (aerosol radiative forcing per unit of aerosol optical depth) during these desert dust events was analyzed according to desert dust sources.

For this task the daily values of the ARF at the surface and TOA were computed. To simulate solar irradiance values we used the SBDART radiative transfer code. As input parameters the columnar aerosol properties retrieved from the solar direct irradiance and the principal plane sky radiance measurements by an AERONET CIMEL sun-photometer were used. The spectral aerosol optical properties are obtained using the methodology described by Alados-Arboledas et al. (2003) and Olmo et al. (2008). The principal plane inversion method used is based on the method developed by Nakajima et al. (1996), updated to account for particle nonsphericity in the modeling of aerosol properties by Olmo et al. (2008). As input parameters in the inversion code, we used the spectral normalized sky radiance and the spectral aerosol optical depth. To eliminate cloud-contaminated cases, we applied the triplet stability criteria to the aerosol optical depth measurements and smoothed sky radiance measurements with a five-point moving-average. Additionally, the residuals between the measured and computed spectral normalized sky radiances were required to be less than $10 \%$. The inversion methodology was checked against simulated data from aerosol models, and the derived aerosol properties were satisfactorily compared against well-known AERONET products.

The global irradiances simulated by the SBDART radiative transfer code have been evaluated by comparison with experimental global irradiance values measured with a CM11 pyranometer. Agreement was good with a mean bias around $3 \%$. Moreover, the simulated instantaneous solar global irradiances were validated against those provided by AERONET. In general, the agreement was acceptable between AERONET and SBDART for both downward fluxes at surface and upward fluxes at TOA. The results show that the aerosol optical properties used to estimate ARF in this work appropriately represent the aerosol properties observed during desert dust outbreak over our study area.

The evolution of ARF mean monthly values (computed from daily ARF values) obtained during desert dust events and analyzed in this study ranged from $-13 \pm 8 \mathrm{~W} \mathrm{~m}^{-2}$ to $-34 \pm 15 \mathrm{~W} \mathrm{~m}^{-2}$ at the surface and from $-4 \pm 3 \mathrm{~W} \mathrm{~m}^{-2}$ to $-13 \pm 7 \mathrm{~W} \mathrm{~m}^{-2}$ at TOA. The largest monthly mean values (in absolute sense) of ARF, both at the surface and TOA, were obtained in April, coinciding with the highest mean monthly value of the aerosol optical depth at $440 \mathrm{~nm}$.

The mean monthly values of atmospheric ARF (ARF at TOA minus ARF at surface) varied from $+6 \pm 4$ to $+21 \pm 12 \mathrm{~W} \mathrm{~m}^{-2}$; the corresponding aerosol atmospheric heating rates, for the entire atmospheric column, range from $0.05 \pm 0.04 \mathrm{~K} \mathrm{day}^{-1}$ to $0.19 \pm 0.10 \mathrm{~K} \mathrm{day}^{-1}$.

The mean ARFE values at the surface (TOA) has been classified according to the desert dust sources, being $-20 \pm 12(-5 \pm 5) \mathrm{W} \mathrm{m}^{-2},-21 \pm 9(-7 \pm 5) \mathrm{W} \mathrm{m}^{-2}$ and $-18 \pm 9(-6 \pm 5) \mathrm{W} \mathrm{m}^{-2}$ for sectors A (northern Morocco; northwestern Algeria), B (western Sahara, northwestern Mauritania and southwestern Algeria), and C (eastern Algeria, Tunisia), respectively. The Kolmogorov-Smirnov statistical test revealed that there are no significant differences between the daily ARF values at the surface obtained for the different desert dust sources. However, this test showed that daily ARF values at TOA for sector A were significantly different from the other two sectors, likely as a result of the lower values of single scattering albedo (high aerosol absorption) obtained for sector A in comparison to the other sectors.

The daily values of aerosol radiative forcing efficiency (ARFE-aerosol radiative forcing per unit of aerosol optical depth at $440 \mathrm{~nm}$ ) at the surface and TOA were also evaluated according to the desert dust source. The mean ARFE values at the surface (TOA) were $-74 \pm 12 \mathrm{~W} \mathrm{~m}^{-2}\left(-17 \pm 7 \mathrm{~W} \mathrm{~m}^{-2}\right)$ for sector $\mathrm{A}$, $-70 \pm 14 \mathrm{~W} \mathrm{~m}^{-2}\left(-20 \pm 9 \mathrm{~W} \mathrm{~m}^{-2}\right)$ for sector $\mathrm{B}$, and $-65 \pm 16 \mathrm{~W} \mathrm{~m}^{-2}\left(-22 \pm 10 \mathrm{~W} \mathrm{~m}^{-2}\right)$ for sector $\mathrm{C}$, being comparable between the three sectors in all seasons.

\section{Appendix A}

\section{Accuracy assessment of individual retrievals using the} principal plane inversion method

To analyze the accuracy of individual retrievals of the principal plane inversion method used in this work, an extensive 

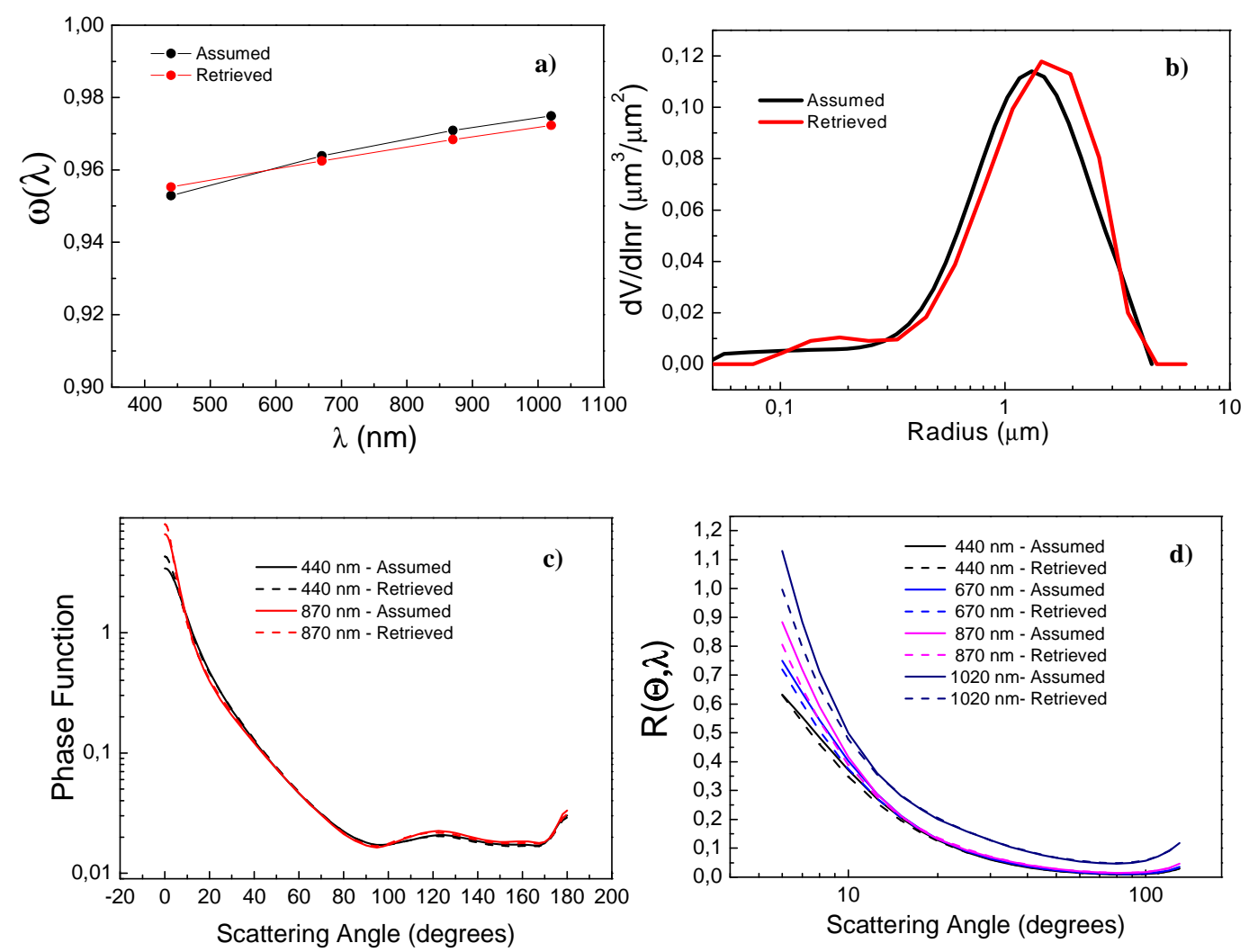

Fig. A1. Assumed and retrieved data for the analyzed case presented in Table A1: (a) spectral single scattering albedo, (b) volume size distribution, (c) spectral phase function, and (d) spectral normalized sky radiance in the principal plane.

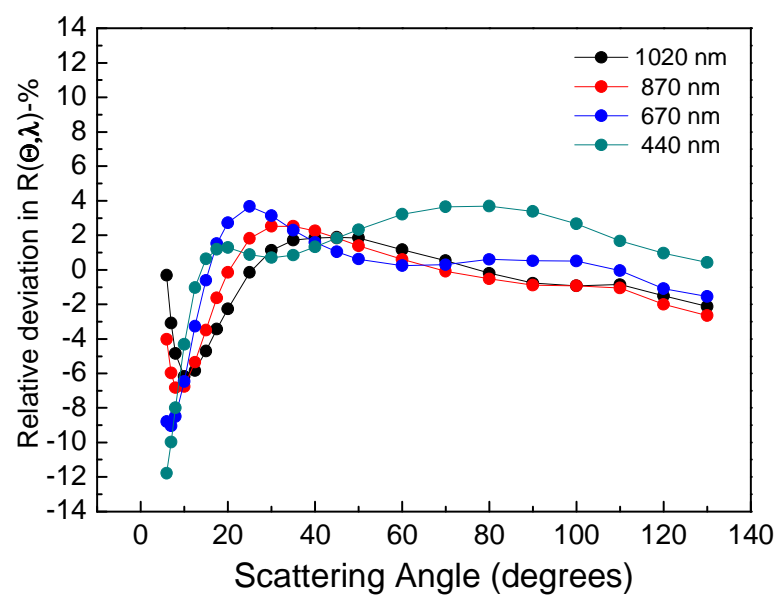

Fig. A2. Relative deviations between assumed and retrieved $R(\Theta, \lambda)$ for the analyzed case presented in Table A1.

sensitivity test was performed using assumed and retrieved aerosol properties for cases characterized by different loads of mineral dust particles. The purpose of the sensitivity tests was to verify the algorithm efficiency and check the results regarding the setting of the inversion algorithm.
We have generated a set of synthetic data using the direct code (MKDTA software) included in the SKYRAD.PACK code, replacing the spherical kernels by the nonspherical kernels computed in Olmo et al. (2008). These synthetic data (assumed data) are computed by varying the particle mean radius, the volume concentrations, the standard deviations and the refractive index (different dust-like aerosol models). In these tests the properties of the fine mode are assumed as constant. The analysis was performed for $440,670,870$ and $1020 \mathrm{~nm}$ wavelengths, and the maximum scattering angle used was $140^{\circ}$.

Then, we applied the principal plane inversion algorithm to derive the aerosol optical parameters, using as input parameters the spectral aerosol optical depth and the normalized sky radiances retrieved by the direct method. The differences between retrieved and assumed values of aerosol properties give the apparent retrieval errors inherent to the inversion algorithm.

The following equation describes the bimodal log-normal model assumed in the simulations:

$$
\frac{d V(r)}{d \ln r}=\sum_{i=1}^{2} \frac{V_{i}}{\sqrt{2 \pi \sigma_{i} r}} \exp \left[-\frac{\left(\ln r-\ln r_{i}\right)^{2}}{2 \sigma_{i}^{2}}\right]
$$



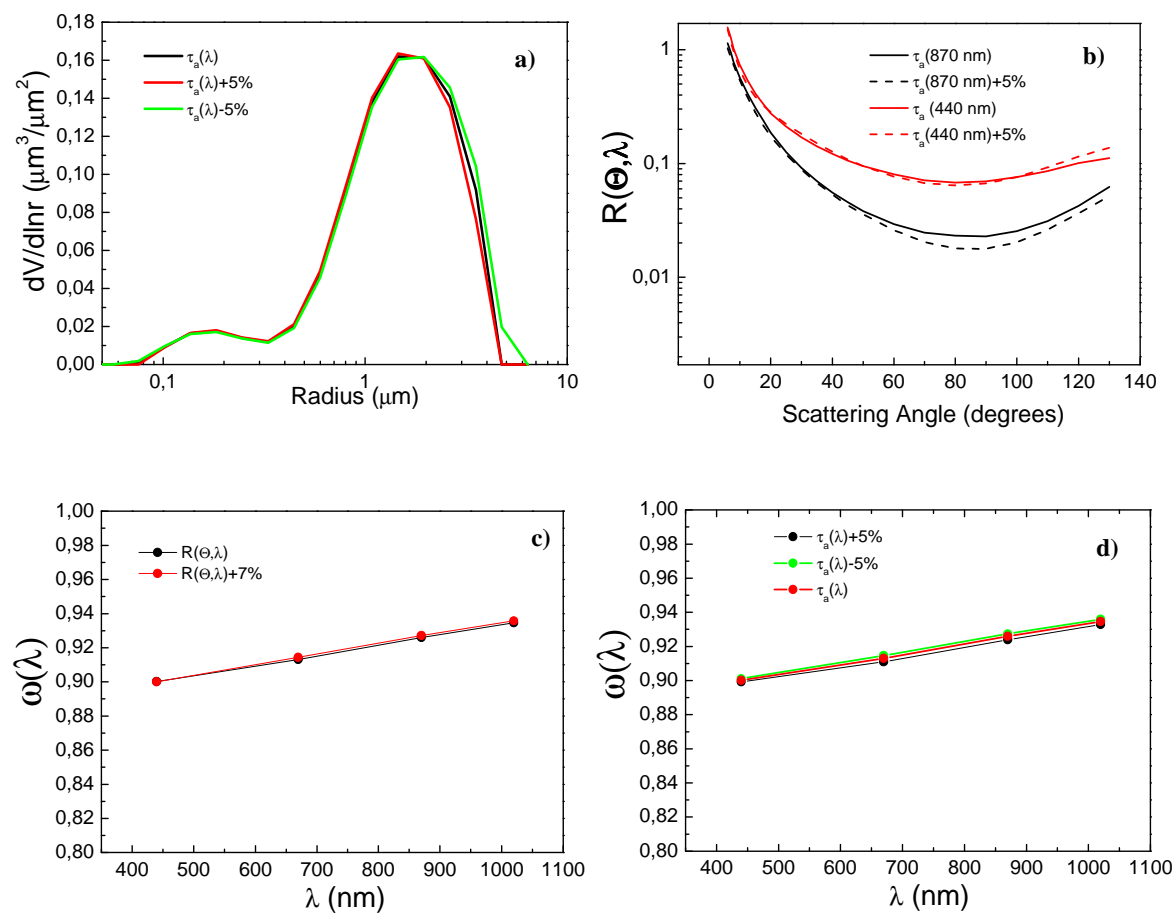

Fig. A3. Retrieval results with and without errors in input data for the Saharan dust case detected over Granada on 23 June 2008. (a) Volume size distribution retrievals derived using as input parameters $\tau_{a}(\lambda), \tau_{a}(\lambda)-5 \%$ and $\tau_{a}(\lambda)+5 \% ;(\mathbf{b}) R(\Theta, \lambda)$ retrievals derived using as input parameters $\tau_{a}(\lambda), \tau_{a}(\lambda)-5 \%$ and $\tau_{a}(\lambda)+5 \%$; (c) $\omega(\lambda)$ retrievals derived using as input parameters $R(\Theta, \lambda)$ and $R(\Theta, \lambda)+7 \%$, and $(\mathbf{d}) \omega(\lambda)$ retrievals derived using as input parameter $\tau_{a}(\lambda), \tau_{a}(\lambda)-5 \%$ and $\tau_{a}(\lambda)+5 \%$.

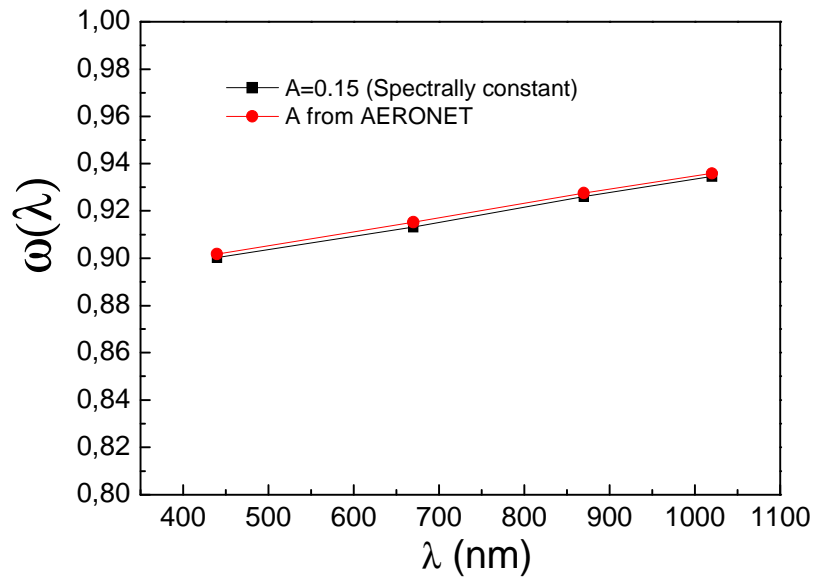

Fig. A4. $\omega(\lambda)$ retrievals derived for desert dust case (23 June 2008) using a spectrally constant value of 0.15 for the surface albedo (A), and using the spectrally dependent values of A provided by AERONET network.

where $d V(r) / d \ln r$ is the particle volume size distribution, $r$ is the particle radius, $i$ denotes fine or coarse modes, $V_{i}$ is the volume concentrations, and $\sigma_{i}$ the standard deviations.

Table A1 shows an example of the assumed parameters used in the sensitivity tests. Considering the importance of aerosol absorption in radiative forcing, it is also of interest to evaluate the agreement between the assumed (direct method) and retrieved (inversion algorithm) values of single scattering albedo. Figure A1 shows the assumed and retrieved effective single scattering albedo, volume size distribution, phase function and normalized sky radiances for the example presented in Table A1. As seen in Fig. A1, the retrieved aerosol properties by the inversion procedure were close to the assumed values. The RMSE \% (root mean square error) computed for the data sets (assumed vs. retrieved) in Fig. A1, including all wavelengths and/or scattering angles for each data set, is close to $1 \%$ for single scattering albedo, close to $2 \%$ for phase functions and close to $3 \%$ for normalized sky radiances. For the volume size distribution, the RMSE $\%$ are close to $3 \%$ in coarse mode, but could increase up to $30 \%$ for radius close to 0.1 and $7 \mu \mathrm{m}$. Outside this range of radius the RMSE \% increases drastically.

Figure A2 shows the relative deviations between the assumed and retrieved $R(\Theta, \lambda)$ for the analyzed case (Table A1), that is computed as follows:

$$
\frac{\left(R_{\text {Retrieved }}(\Theta, \lambda)-R_{\text {Assumed }}(\Theta, \lambda)\right)}{R_{\text {Assumed }}(\Theta, \lambda)} .
$$

As seen in Fig. A2, the relative deviations have a clear angular dependence that increases for lower scattering angles and reaches a maximum of $12 \%$ at scattering angles close to $6^{\circ}$. 
Table A1. Example of the assumed aerosol parameters used in the sensitivity tests (f: fine mode, c: coarse mode).

\begin{tabular}{lr}
\hline Volume mean radius & $\begin{array}{r}r_{f}=0.16 \\
r_{c}=1.33\end{array}$ \\
\hline Ratio of particle volume concentration & $\mathrm{V}_{f} / \mathrm{V}_{c}=0.05$ \\
\hline Standard deviations & $\sigma_{\mathrm{f}}=0.25$ \\
& $\sigma_{\mathrm{c}}=0.52$ \\
\hline Refractive Index & $n=1.51$ \\
& $k=-0.002$ \\
\hline
\end{tabular}

Similar results are obtained for the different dust-like aerosol models tested using the spheroid model. In all cases, the optical parameter retrievals were performed with RMSE $\%$ close to $5 \%$ or less, and close to $10 \%$ or less for normalized sky radiances and volume size distributions. These results are in agreement with the criteria used in the inversion algorithm for the cloud-screening method and also with the minimization of the normalized sky radiance residuals in the iterative procedure.

On the other hand, to analyze the behavior of the inversion code-taking into account the possible errors on input parameters, e.g., calibration or systematic errors-we have performed different tests on data with errors of $3 \%$ and $5 \%$ (also $7 \%$ ), in $\tau_{a}(\lambda), R(\Theta, \lambda)$ surface albedo and refractive index. These error variations also include the possible errors in radiance calibrations (e.g. Torres, 2012). For example, Fig. A3 shows different retrievals obtained from experimental data corresponding to the Saharan dust event that affected Granada on 23 June 2008. In this case, we assumed errors of $5 \%$ and $7 \%$ in $\tau_{a}(\lambda)$ and $R(\Theta, \lambda)$. The RMSE $\%$ for the data sets presented in Fig. A3 is less than $5 \%$ in all cases. Also, the different tests performed show that the differences between assumed (without errors) and retrieved (with errors) optical parameters, in absence of strong systematic biases, is about $5 \%$ or less in all cases. Therefore, this residual value can be adopted as an indicator of the quality of the retrievals.

In addition, Fig. A4 shows the effective $\omega(\lambda)$ derived for this dust event using a spectrally constant value for the surface albedo (0.15) and using the spectrally dependent surface albedo provided by AERONET network. The results show, in agreement with other authors (e.g. Dubovik and King, 2000; Dubovik et al., 2002b), that the $\omega(\lambda)$ is minimally affected by surface albedo.

Finally, using this methodology and in view of the previous results, the accuracies of single scattering albedo and asymmetry parameter retrievals, using scattering angles up to $100^{\circ}$ or greater, are about $5 \%$ for different mineral aerosol loading. For volume size distributions, the error depends on the particle size. For the radius interval 0.1-7 $\mu \mathrm{m}$, the retrieval errors do not exceed $10 \%$. Even taking into account the limitations of this methodology, these results are comparable to those derived by other authors using the almucantar configuration (e.g. Dubovik and King, 2000; Dubovik et al., 2002b).

Acknowledgements. This work was supported by the Andalusia Regional Government through projects P08-RNM-3568 and P10-RNM-6299, by the Spanish Ministry of Science and Technology through projects CGL2010-18782, CSD2007-00067 and CGL2011-13580-E/CLI; and by EU through ACTRIS project (EU INFRA-2010-1.1.16-262254). The authors thankfully acknowledge the computer resources, technical expertise and assistance provided by the Barcelona Supercomputing Center. ALFA database computation was partly supported by RES (Spanish Supercomputation Network) computing resources (projects AECT-2009-1-0012, AECT-2011-3-0016). We are in debt to Oleg Dubovik and the anonymous reviewers that have contributed to improve the quality of the paper with their comments and suggestions. We also thank Dr Andrew Kowalski for revising the manuscript.

Edited by: O. Dubovik

\section{References}

Alados-Arboledas, L., Lyamani, H., and Olmo, F. J.: Aerosol size properties at Armilla, Granada (Spain), Q. J. R. Meteorol. Soc., 129, 1395-1413, 2003.

Alados-Arboledas, L., Alcántara, A., Olmo, F. J., Martínez-Lozano, J. A., V. Estellés, Cachorro, V., Silva, A. M., Horvath, H., Gangl, M., Díaz, A., Pujadas, M., Lorente, J., Labajo, A., Sorribas, M., and Pavese, G.: Aerosol columnar properties retrieved from CIMEL radiometers during VELETA 2002, Atmos. Environ., 42, 2654-2667, 2008.

Alam, K., Trautmann, T., Blaschke, T., and Majid, H.: Aerosol optical and radiative properties during summer and winter seasons over Lahore and Karachi, Atmos. Environ., 50, 234-245, 2012.

Antón, M., Valenzuela, A., Cazorla, A., Gil, J. E., FernándezGálvez, J., Lyamani, H., Foyo-Moreno, I., Olmo, F.J., AladosArboledas, L: Global and diffuse shortwave irradiance during a strong desert dust episode at Granada (Spain), Atmos. Res., 118, 232-239, 2012.

d'Almeida, G. A., Koepke, P., and Shettle, E. P.: Atmospheric Aerosols: Global Climatology and Radiative Characteristics, A. Deepak Publishing, Hampton, VA, 1991.

Antón, M., Gil, J. E., Fernández-Gálvez, J., Lyamani, H., Valenzuela, A., Foyo-Moreno, I., Olmo, F. J., and Alados-Arboledas, L.: Evaluation of the aerosol forcing efficiency in the UV erythemal range at Granada, Spain, J. Geophys. Res., 116, D20214, doi:10.1029/2011JD016112, 2011.

Bauer, S., Bierwirth, E., Esselborn, M., Petzold, A., Macke, A., Trautmann, T., and Wendisch, M.: Airborne spectral radiation measurements to derive solar radiative forcing of Saharan dust mixed with biomass burning smoke particles, Tellus 63B, 742750, 2011.

Bellantone, V., Carofalo, I., De Tomasi, F., Perrone, M. R., Santese, M., Tafuro, A. M., Turnone, A.: In situ samplings and remote sensing measurements to characterize aerosol properties over South-East Italy, J. Atmos. Oceanic Technol., 25, 13411356, 2008. 
Boucher, O., Schwartz, S.E., Ackerman, T.P., Anderson, T.L., Bergstrom, B., Bonnel, B., Chylek, P., Dahlback, A., Fouquart, Y., Fu, Q., Halthore, R.N., Haywood, J.M., Iversen, T., Kato, S., Kinne, S., Kirkevag, A., Knapp, K.R., Lacis, A., Laszlo, I., Mishchenko, M.I., Nemesure, S., Ramaswamy, V., Roberts, D.L., Russell, P., Schlesinger, M.E., Stephens, G.L., Wagener, R., Wang, M., Wong, J., Yang, F.: Intercomparison of models representing direct shortwave radiative forcing by sulfate aerosols, J. Geophys. Res., 103, 16979-16998, 1998.

Bush, B. C. and Valero, F. P. J.: Surface aerosol radiative forcing at Gosan during the ACE-Asia campaign, J. Geophys. Res., 108, 8660, doi:10.1029/2002JD003233, 2003.

Carofalo, I., Fermo, P., Perrone, M. R., and Piazzalunga, A.: Advection patterns and composition of TSP and $\mathrm{PM}_{2.5}$ samples over south-east Italy, Proc. Chem. Eng. Trans. 18, 185-192, 2008.

Cachorro, V. E., Toledano, C., Prats, N., Sorribas, M., Mogo, S., Berjón, A., Torres, B., Rodrigo, R., de la Rosa, J., and De Frutos, A. M.: The strongest desert dust intrusion mixed with smoke over the Iberian Peninsula registered with Sun photometry, J. Geophys. Res., 113, D14S04, doi:10.1029/2007JD009582, 2008.

Cazorla, A., Olmo, F. J., and Alados-Arboledas, L.: Development of a sky imager for cloud covers assessment, J. Opt. Soc. Am.-A, 25, 29-38, 2008.

Cazorla, A., Shields, J. E., Karr, M. E., Olmo, F. J., Burden, A., and Alados-Arboledas, L.: Technical Note: Determination of aerosol optical properties by a calibrated sky imager, Atmos. Chem. Phys., 9, 6417-6427, doi:10.5194/acp-9-6417-2009, 2009.

Derimian, Y., Karnieli, A., Kaufman, Y. J., Andreae, M. O., Andreae, T. W., Dubovik, O., Maenhaut, W., Koren, I., and Holben, B. N.: Dust and pollution aerosols over the Negev desert, Israel: Properties, transport, and radiative effect, J. Geophys. Res., 111, D05205, doi:10.1029/2005JD006549, 2006.

Derimian, Y., Leon, J. F., Dubovik, O., Chiapello, I., Tanre, D., Sinyuk, A., Auriol, F., Podvin, T., Brogniez, G., and Holben, B. N.: Radiative properties of aerosol mixture observed during the dry season 2006 over M'Bour, Senegal (African Monsoon Multidisciplinary Analysis campaign), J. Geophys. Res., 113, D00C09, doi:10.1029/2008JD009904, 2008.

Di Biagio, C., di Sarra, A., Meloni, D., Monteleone, F., Piacentino, S., and Sferlazzo, D.: Measurements of Mediterranean aerosol radiative forcing and influence of the single scattering albedo, J. Geophys. Res., 114, D06211, doi:10.1029/2008JD011037, 2009.

Di Sarra, A., di Biagio, C., Meloni, D., Monteleone, F., Pace, G., Pugnaghi, S., and Sferlazzo, D.: Shortwave and longwave radiative effects of the intense Saharan dust event of 25-26 March 2010 at Lampedusa (Mediterranean Sea), J. Geophys. Res., 116, D23209, doi:10.1029/2011JD016238, 2011.

Dubovik, O., Smirnov, A., Holben, B.N., King, M.D., Kaufman, Y.J., Eck, T.F., I. Slutsker, I.: Accuracy assessment of aerosol optical properties retrieved from Aerosol Robotic Network (AERONET) Sun and sky radiance measurements, J. Geophys. Res, 105, 9791-9806, 2000.

Dubovik, O., Holben, B. N., Lapyonok, T., Sinyuk, A., Mishchenko, M. I., Yang P., and Slutsker, I.: Non-spherical aerosol retrieval method employing light scattering by spheroids, Geophys. Res. Lett., 29, 1415, doi:10.1029/2001GL014506, 2002a.

Dubovik, O., Holben, B., Eck, T. F., Smirnov, A., Kaufman, Y. J., King, M. D., Tanre, D., and Slutsker, I.: Variability of absorption and optical properties of key aerosol types observed in world- wide locations, J. Atmos. Sci., 59, 590-608, 2002 b.

Dubovik, O., Sinyuk, A., Lapyonok, T., Holben, B. N., Mishchenko, M., Yang, P., Eck, T. F., Volten, H., Muñoz, O., Veihelmann, B., van der Zande, W. J., Leon, J. F., Sorokin, M., and Slutsker, I.: Application of spheroid models to account for aerosol particle nonsphericity in remote sensing of desert dust, J. Geophys. Res., 111, D11208, doi:10.1029/2005JD006619, 2006.

Dubovik, O. and King M. D.: A flexible inversion algorithm for retrieval of aerosol optical properties from sun and sky radiance measurements, J. Geophys. Res., 105, 20673-20696, 2000.

Draxler, R. R. and Rolph, G.: HYSPLIT (Hybrid Single-Particle Lagrangian Integrated Trajectory) Model, NOAA Air Resour. Lab. Silver Spring, Md. available at: http://www.arl.noaa.gov/ready/ hysplit4.html, 2003.

Eck, T. F., Holben, B. N., Sinyuk, A., Pinker, R. T., Goloub, P., Chen, H., Chatenet, B., Li, Z., Singh, R. P., Tripathi, S. N., Reid, J. S., Giles, D. M., Dubovik, O., O’Neill, N. T., Smirnov, A., Wang, P., and Xia, X.: Climatological aspects of the optical properties of fine/coarse mode aerosol mixtures, J. Geophys. Res., 115, D19205, doi:10.1029/2010JD014002, 2010.

Foster, P., Ramaswamy, V., Artaxo, P., Berntsen, T., Betts, R., Fahey, D. W., Haywood, J., Lean, J., Lowe, D. C., Myhre, G., Nganga, J., Prinn, R., Raga, G., Schulz, M., and Van Dorland, R.: Changes in Atmospheric Constituents and in Radiative Forcing, in: Climate Change 2007: The Physical Science Basis, Contribution of Working Group I to the Fourth Assessment Report of the Intergovernmental Panel on Climate Change, edited by: Solomon, S., Qin, D., Manning, M., Chen, Z., Marquis, M. , Averyt, K. B., Tignor, M., and Miller, H. L., Cambridge University Press, Cambridge, United Kingdom and New York, NY, USA, 2007.

Gangoiti, G., Alonso, L., Navazo, M., García, J. A., and Millán, M. M.: North African soil dust and European pollution transport to America during the warm season: Hidden links shown by a passive tracer simulation, J. Geophys. Res., 111, D10109, doi:10.1029/2005JD005941, 2006.

Garcia, O. E., Exposito, F. J., Diaz, J. P., and Diaz, A. M.: Radiative forcing under mixed aerosol conditions, J. Geophys. Res., 116, D01201, doi:10.1029/2009JD013625, 2011.

Gerasopoulos, E., Andreae, M. O., Zerefos, C. S., Andreae, T. W., Balis, D., Formenti, P., Merlet, P., Amiridis, V., and Papastefanou, C.: Climatological aspects of aerosol optical properties in Northern Greece, Atmos. Chem. Phys., 3, 2025-2041, doi:10.5194/acp-3-2025-2003, 2003.

Guerrero-Rascado, J. L., Ruiz, B., and Alados-Arboledas, L.: Multispectral Lidar characterization of the vertical structure of Saharan dust aerosol over southern Spain, Atmos. Environ., 42, 2668 2681, 2008.

Guerrero-Rascado, J. L., Olmo, F. J., Avilés-Rodríguez, I., NavasGuzman, F., Pérez-Ramírez, D., Lyamani, H., and Alados Arboledas, L.: Extreme Saharan dust event over the southern Iberian Peninsula in september 2007: active and passive remote sensing from surface and satellite, Atmos. Chem. Phys., 9, 84538469, doi:10.5194/acp-9-8453-2009, 2009.

Holben, B. N., Eck, T. F., Slutsker, I., Tanre, D., Buis, J. P., Setzer, A., Vermote, E., Reagan, J. A., Kaufman, Y. J., Nakajima, T., Lavenu, F., Jankowiak, I., Smirnov, A.: AERONET - A federated instrument network and data archive for aerosol characterization, Remote Sens. Environ., 66, 1-16, 1998. 
Huang, J., Fu, Q., Su, J., Tang, Q., Minnis, P., Hu, Y., Yi, Y., and Zhao, Q.: Taklimakan dust aerosol radiative heating derived from CALIPSO observations using the Fu-Liou radiation model with CERES constraints, Atmos. Chem. Phys., 9, 4011-4021, doi:10.5194/acp-9-4011-2009, 2009.

Kandler, K., Benker, N., Bundke, U., Cuevas, E., Ebert, M., Knippertz, P., Rodríguez, S., Schützd, L., and Weinbruch, S.: Chemical composition and complex refractive index of Saharan Mineral Dust at Izaña, Tenerife (Spain) derived by electron microscopy, Atmos. Environ., 41, 8058-8074, 2007.

Kim, D. H., Sohn, B. J., Nakajima, T., and Takamura, T.: Aerosol radiative forcing over east Asia determined from ground-based solar radiation measurements, J. Geophys. Res., 110, D10S22, doi:10.1029/2004JD004678, 2005.

Kneizys, F. X., Shettle E. P., Abreu, L. W., Chetwind, J. H., Anderson, G. P., Gallery W. O., Selby, J. E. A., and Clough, S. A.: Users guide to LOWTRAN7, Environmental research paper 1010. Bedford, MA: US Air Force Geophys. Lab., 1988.

Koren, I., Ganor, E., and Joseph, J. H.: On the relation between size and shape of desert dust aerosol, J. Geophys. Res., 106, 1804718054, 2001.

Kobayashi, E., Uchiyama, A., Yamazaki, A., and Kudo, R.: Retrieval of Aerosol Optical Properties Based on the Spheroid Model, J. Meteorol. Soc. Jpn., 88, 847-856, 2010.

Kubilay, N., Cokacar, T., and Oguz, T.: Optical properties of mineral dust outbreaks over the northeastern Mediterranean, J. Geophys. Res., 108, 4666, doi:10.1029/2003JD003798, 2003.

Li, Z., Goloub, P., Devaux, C., Gu, X., Qiao, Y., Zhao, F., and Chen, H.: Aerosol polarized phase function and single scattering albedo retrieved from ground-based measurements, Atmos. Res., 71, 233-241, 2004.

Liou, K.N.: An introduction to Atmospheric Radiation, Elsevier, New York, USA, 583 pp., 2002.

Lucht, W. and Roujean, J. L.: Consideration in parametric modeling of BRDF and albedo from multi-angular satellite sensors observations, Remote Sens. Rev., 18, 343-379, 2000.

Lyamani, H., Olmo, F. J., and Alados-Arboledas, L.: Saharan dust outbreak over southeastern Spain as detected by sun photometer, Atmos. Environ., 39, 7276-7284, 2005.

Lyamani, H., Olmo, F. J., Alcántara, A., and Alados-Arboledas, L.: Atmospheric aerosols during the 2003 heat wave in southeastern Spain I: Spectral optical depth, Atmos. Environ., 40-33, 64536464, 2006a.

Lyamani, H., Olmo, F. J., Alcántara, A., and Alados-Arboledas, L.: Atmospheric aerosols during the 2003 heat wave in southeastern Spain II: Microphysical columnar properties and radiative forcing, Atmos. Environ., 40, 6465-6476, 2006b.

Meloni, D., di Sarra, A., Di Iorio, T., and Fiocco G.: Influence of the vertical profile of Saharan dust on the visible direct radiative forcing, J. Quant. Spectrosc. Radiat. Transfer, 93, 397-413, 2005.

Mishchenko M. I.: Light scattering by size-shape distributions of randomly oriented axially symmetric particles of a size comparable to a wavelength, Appl. Opt., 32, 4652-4666, 1993.

Mishchenko, M. I., Travis, L. D., Kahn, R. A., and West, R. A.: Modeling phase functions for dust like tropospheric aerosols using a shape mixture of randomly oriented polydisperse spheroids, J. Geophys. Res., 102, 16831-16848, 1997.
Moody, E.G., King, M. D., Platnick, S., Schaaf C.B., and Gao F.: Spatially complete global spectral surface albedos: valueadded datasets derived from Terra MODIS land products, IEEE T. Geosci. Remote., 43, 144-158, 2005.

Muñoz, O., Volten, H., de Haan, J. F., Vassen, W., and Hovenier, J. W.: Experimental determination of scattering matrices of randomly oriented fly ash and clay particles at 442 and $633 \mathrm{~nm}$, J. Geophys. Res., 106, 22833-22844, 2001.

Myhre, G., Grini, A., Haywood, J. M., Stordal, F., Chatenet, B., Tanre, D., Sundet, J. K., and Isaksen, I. S. A.: Modeling the radiative impact of mineral dust during the Saharan Dust Experiment (SHADE) campaign J. Geophys. Res., 108, 8579, doi:10.1029/2002JD002566, 2003.

Nakajima, T., Tonna, G., Rao, R. Z., Boi, P., Kaufman, Y., and Holben, B.: Use of sky brightness measurements from ground for remote sensing of particulate polydispersions, Appl. Opt., 35, 2672-2686, 1996.

Olmo, F. J., Quirantes, A., Alcantara, A., Lyamani, H., and AladosArboledas, L.: Preliminary results of a non-spherical aerosol method for the retrieval of the atmospheric aerosol optical properties, J. Quant. Spectrosc. Radiat. Transfer., 100, 305-314, 2006.

Olmo, F. J., Quirantes, A., Lara, V., Lyamani, H., and AladosArboledas, L.: Aerosol optical properties assessed by an inversion method using the solar principal plane for non-spherical particles, J. Quant. Spectrosc. Radiat. Transfer., 109, 1504-1516, 2008.

Otto, S., Bierwirth, E., Weinzierl, B., Kandler, K., Esselborn, M., Tesche, M., Schladitz, A., Wendisch, M. and Trautmann, T.: Solar radiative effects of a Saharan dust plume observed during SAMUM assuming spheroidal model particles, Tellus 61B, 270296, 2009.

Papayannis, A., Amiridis, V., Mona, L., Tsaknakis, G., Balis, D., Bösenberg, J., Chaikovski, A., De Tomasi, F., Grigorov, I., Mattis, I., Mitev, V., Müller, D., Nickovic, S., Pérez, C., Pietruczuk, A., Pisani, G., Ravetta, F., Rizi, V., Sicard, M., Trickl, T., Pandithurai, G., Seethala, C., Murthy, B. S., and Devara, P. C. S.: Investigation of atmospheric boundary layer characteristics for different aerosol absorptions: Case studies using CAPS model, Atmos. Environ., 42, 4755-4768, 2008.

Perrone, M. R. and Bergamo, A.: Direct radiative forcing during Sahara dust intrusions at a site in the Central Mediterranean: Anthropogenic particle contribution, Atmos. Res. doi:10.1016/jatmosres.2011.05.011, 2011.

Pilinis, C. and Li, X.: Particle shape and internal inhomogeneity effects in the optical properties of tropospheric aerosols of relevance to climate forcing, J. Geophys. Res., 103, 3789-3800, 1998.

Pinker, R. T., Liu, H., Osborne, S. R., and Akoshile, C.: Radiative effects of aerosols in sub-Sahel Africa: Dust and biomass burning, J. Geophys. Res., 115, D15205, doi:10.1029/2009JD013335, 2010.

Prasad, A. K., Singh, S., Chauhan, S. S., Srivastava, M. K., Singh, R. P., and Singh, R.: Aerosol radiative forcing over the IndoGangetic plains during major dust storms, Atmos. Environ., 41, 6289-6301, 2007.

Prospero, J. M., Ginoux, P., Torres, O., Nicholson, S. E., and Gill, T. E.: Environmental characterization of global sources of atmospheric soil dust identified with the Nimbus 7 Total Ozone 
Mapping Spectrometer (TOMS) absorbing aerosol product, Rev. Geophys, 40, 1002, doi:10.1029/20000GR000095, 2002.

Ricchiazzi, P., Yang, S., Gautier, C., and Sowle, D.: SBDART: A research and teaching software tool for plane-parallel radiative transfer in the Earth's atmosphere, Bull. Am. Meteorol. Soc., 79, 2101-2114, 1998.

Rodríguez, S., Alastuey, A., Alonso-Pérez, S., Querol, X., Cuevas, E., Abreu-Afonso, J., Viana, M., Pérez, N., Pandolfi, M., and de la Rosa, J.: Transport of desert dust mixed with North African industrial pollutants in the subtropical Saharan Air Layer, Atmos. Chem. Phys., 11, 6663-6685, doi:10.5194/acp-11-66632011, 2011.

Saha, A., Mallet, M., Roger, J. C., Dubuisson, P., Piazzola, J., and Despiau, S.: One year measurements of aerosol optical properties over an urban coastal site: Effect on local direct radiative forcing, Atmos. Res., 90, 195-202, 2008.

Smirnov, A., Holben, B. N., Eck, T. F., Dubovik, O., and Slutsker, I.: Cloud-screening and quality control algorithms for the AERONET database, Remote Sens. Rev., 73, 337-349, 2000.

Sokolik, I. N. and Toon, O. B.: Incorporation of mineralogical composition into models of the radiative properties of mineral aerosol from UV to IR wavelengths, J. Geophys. Res., 104, 9423-9444, 1999.

Stamnes, K., Tsay, C., Wiscombe, W., and Jayaweera, K.: Numerically stable algorithm for discrete-ordinate-method radiative transfer in multiple scattering and emitting layered media, Appl. Opt., 27, 2502-2509, 1988.

Tafuro, A. M., Barnaba, F., De Tomasi, F., Perrone, M. R., and Gobbi, G. P.: Saharan dust particle properties over the central Mediterranean, Atmos. Res., 81, 67-93, 2006.

Tesche, M., Ansmann, A., Müller, D., Althausen, D., Mattis, I., Heese, B., Freudenthaler, V., Wiegner, M., Esselborn, M., Pisani, G., and Knippertz, P.: Vertical profiling of Saharan dust with Raman lidars and airborne HSRL in southern Morocco during SAMUM, Tellus 61B, 144-164, 2009.

Toledano, C., Cachorro, V. E., de Frutos, A. M., Sorribas, M., Prats, N., and de la Morena, B. A.: Inventory of African desert dust events over the southwestern Iberian Peninsula in 2000-2005 with an AERONET Cimel Sun photometer, J. Geophys. Res., 112, D21201, doi:10.1029/2006JD008307, 2007.
Torres, B.: Study on the influence of different error sources on sky radiance measurements and inversion-derived aerosol products in the frame of AERONET, Ph. D. Atmospheric Optics Group. University of Valladolid, April, 2012.

Valenzuela, A., Olmo, F. J., Lyamani, H., Antón, M., Quirantes, A., and Alados-Arboledas, L.: Analysis of the desert dust radiative properties over Granada using principal plane sky radiances and spheroids retrieval procedure, Atmos. Res., 104-105, 292-301, 2012a.

Valenzuela, A., Olmo, F. J., Lyamani, H., Antón, M., Quirantes, A., and Alados-Arboledas, L.: Classification of aerosol radiative properties during African desert dust intrusions over southeastern Spain by sector origins and cluster analysis, J. Geophys. Res., 117, D06214, doi:10.1029/2011JD016885, 2012b.

Vermeulen, A., Devaux, C., and Herman M.: Retrieval of the scattering and microphysical properties of aerosols from ground.based optical measurements including polarization, I. Method, Appl. Opt., 39, 6207-6220, 2000.

Wagner, F., Bortoli, D., Pereira, S., Costa, M. J., Silva, A. M., Weinzierl, B., Esselborn, M., Petzold, A., Rasp, K., Heinold, B., and Tegen, I.: Properties of dust aerosol particles transported to Portugal from the Sahara desert, Tellus 61B, 297-306, 2009.

Waterman P. C.: Symmetry, unitarity, and geometry in electromagnetic scattering, Phys. Rev, D3, 825-839, 1971.

Won, J.-G., Yoon, S.-C., Kim, S.-W., Jefferson, A., Dutton, E. G., and Holben, B. N.: Estimations of direct radiative forcing of Asian dust aerosols with sun/sky radiometer ans lidar measurements at Gosan, Korea, J. Meteorol. Soc. Jpn., 82, 115-130, 2004.

Yang, P. and Liou, K. N.: Geometric-optics-integral-equation method for light scattering by nonspherical ice crystals, Appl. Opt., 35, 6568-6584, 1996.

Yang, P., Feng, Q., Hong, G., Kattawar, G. W., Wiscombe, W. J., Mishchenko, M. I., Dubovik, O., Laszlo, I., and Sokolik, I. N.: Modeling of the scattering and radiative properties of nonspherical dust particles, J. Aerosol Sci., 38, 995-1014, 2007. 